\title{
ADA 327767
}

\section{US Army Corps}

\section{of Engineers}

\section{U.S. ARMY CZERL LIBRARY

\section{Analysis of LCTA Methods for Inventory and Monitoring Birds and Small Mammals on Army Lands in the Southwestern United States}

by

Clifford G. Rice

Stephen Demarais

Richard W. Hansen

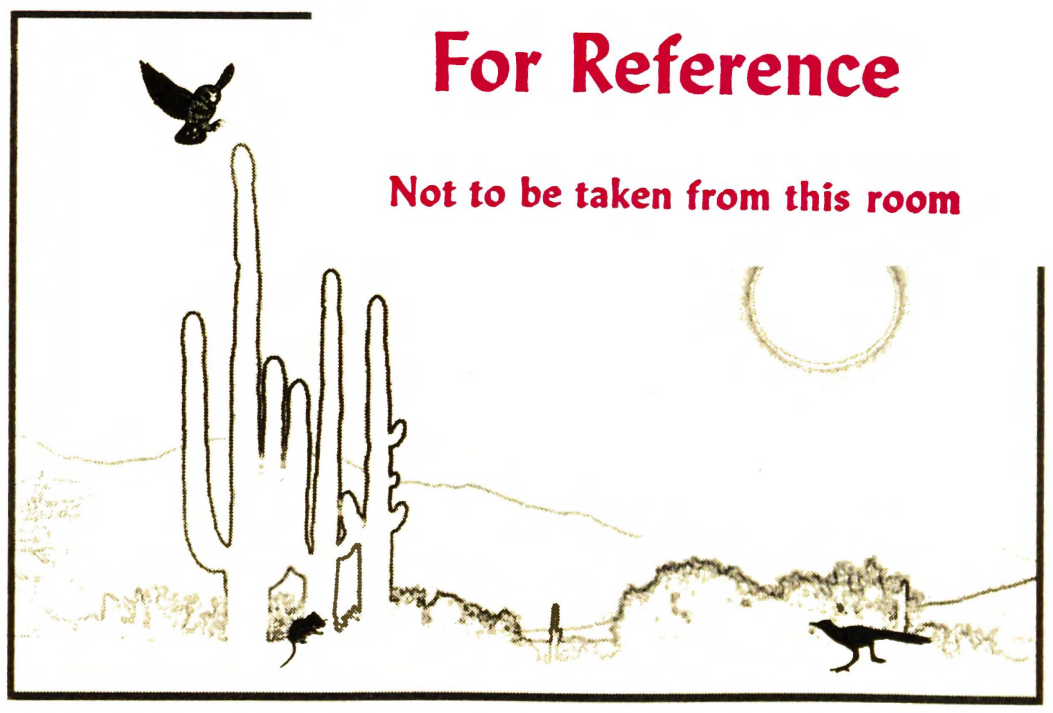

The U.S. Army's Land Condition Trend Analysis (LCTA) Program was established to inventory and monitor ecological systems on Army lands using standard methods. Information obtained using LCTA can help installation resource managers meet multiple-use demands. Although LCTA data have been collected on various installations and analysis is underway, few studies have evaluated whether LCTA methods are effective in detecting ecological changes. One approach to this evaluation is through power analysis.

This study uses power analysis to evaluate bird and small mammal inventory and monitoring protocols in Army lands in the southwestern United States.
Specifically, the study addresses field sampling techniques, sampling design, and analytical approaches and uses four commonly used diversity indices for detecting community differences.

The four diversity indices examined in this study yielded low power in detecting community differences and are consequently poor measures for detecting community change. Statistical power varied between field collection methods. Power also varied between installations, which suggests that standard nationwide sampling protocols will vary in efficiency and effectiveness among locations. 
The contents of this report are not to be used for advertising, publication, or promotional purposes. Citation of trade names does not constitute an official endorsement or approval of the use of such commercial products. The findings of this report are not to be construed as an official Department of the Army position, unless so designated by other authorized documents. 


\section{USER EVALUATION OF REPORT}

REFERENCE: USACERL Technical Report 97/97, Analysis of LCTA Methods for Inventory and Monitoring Birds and Small Mammals on Army Lands in the Southwestern United States

Please take a few minutes to answer the questions below, tear out this sheet, and return it to USACERL. As user of this report, your customer comments will provide USACERL with information essential for improving future reports.

1. Does this report satisfy a need? (Comment on purpose, related project, or other area of interest for which report will be used.)

2. How, specifically, is the report being used? (Information source, design data or procedure, management procedure, source of ideas, etc.)

3. Has the information in this report led to any quantitative savings as far as manhours/contract dollars saved, operating costs avoided, efficiencies achieved, etc.? If so, please elaborate.

4. What is your evaluation of this report in the following areas?

a. Presentation:

b. Completeness:

c. Easy to Understand:

d. Easy to Implement:

e. Adequate Reference Material:

f. Relates to Area of Interest:

g. Did the report meet your expectations?

h. Does the report raise unanswered questions? 
i. General Comments. (Indicate what you think should be changed to make this report and future reports of this type more responsive to your needs, more usable, improve readability, etc.)

5. If you would like to be contacted by the personnel who prepared this report to raise specific questions or discuss the topic, please fill in the following information.

Name:

Telephone Number:

Organization Address:

6. Please mail the completed form to:

Department of the Army CONSTRUCTION ENGINEERING RESEARCH LABORATORIES

ATTN: CECER-TR-I

P.O. Box 9005

Champaign, IL 61826-9005 


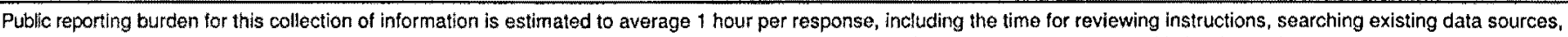

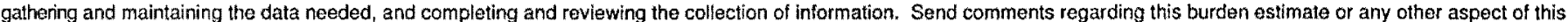

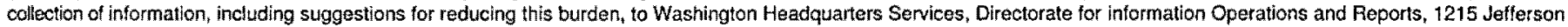
Davis Highway, Sulte 1204, Arlington, VA 22202-4302, and to the Office of Management and Budget, Paperwork Reduction Project (0704-0188), Washington, DC 20503.

\begin{tabular}{|l|l|c|}
\hline 1. AGENCY USE ONLY (Leave Blank) & 2. REPORT DATE \\
June 1997 & 3. REPORT TYPE AND DATES COVERED \\
Final
\end{tabular}

\section{TITLE AND SUBTITLE}

Analysis of LCTA Methods for Inventory and Monitoring Birds and Small Mammals on Army Lands in the Southwestern United States

5. FUNOING NUMBERS

4 A 162720

A 896

WUTY6

6. AUTHOR(S)

Clifford G. Rice, Stephen Demarais, Richard W. Hansen

7. PERFORMING ORGANIZATION NAME(S) AND ADDRESS(ES)

U.S. Army Construction Engineering Research Laboratories (USACERL)

P.O. Box 9005

Champaign, IL 61826-9005

8. PERFORMING ORGANIZATION REPORT NUMBER

TR $97 / 97$

9. SPONSORING / MONITORING AGENCY NAME(S) AND ADDRESS(ES)

Assistant Chief of Staff for Installation Management

ATTN: DAIM-ED-R

600 Army Pentagon, Room 1E682

Washington, DC 20310-0600

\section{SUPPLEMENTARY NOTES}

Copies are available from the National Technical Information Service, 5285 Port Royal Road, Springfield, VA 22161.

12a. DISTRIBUTION/AVAILABILITY STATEMENT

12b. DISTRIBUTION CODE

Approved for public release; distribution is unlimited.

\section{ABSTRACT (Maximum 200 words)}

The U.S. Army's Land Condition Trend Analysis (LCTA) Program was established to inventory and monitor ecological systems on Army lands using standard methods. Information obtained using LCTA can help installation resource managers meet multiple-use demands. Although LCTA data have been collected on various installations and analysis is underway, few studies have evaluated whether LCTA methods are effective in detecting ecological changes. One approach to this evaluation is through power analysis.

This study uses power analysis to evaluate bird and small mammal inventory and monitoring protocols in Army lands in the southwestern United States.

Specifically, the study addresses field sampling techniques, sampling design, and analytical approaches and uses four commonly used diversity indices for detecting community differences.

The four diversity indices examined in this study yielded low power in detecting community differences and are consequently poor measures for detecting community change. Statistical power varied between field collection methods. Power also varied between installations, which suggests that standard nation-wide sampling protocols will vary in efficiency and effectiveness among locations.

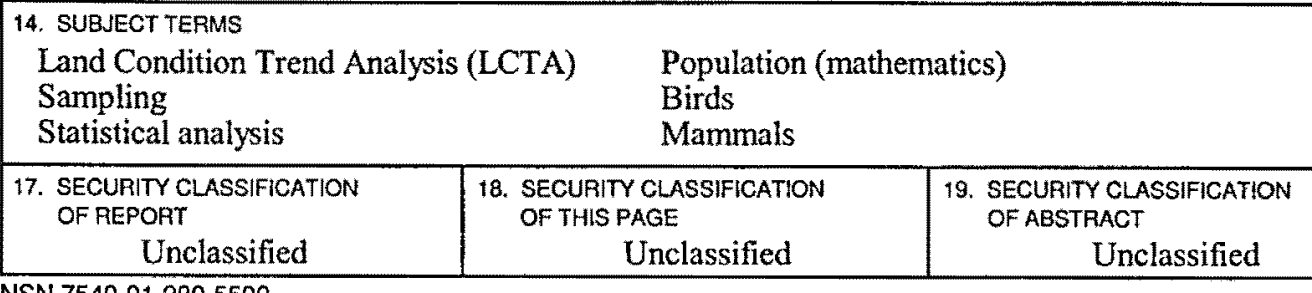




\section{Foreword}

This study was conducted for the Assistant Chief of Staff for Installation Management under Project 4A162720A896, "Environmental Quality Technology"; Work Unit TY6, "Inventory and Monitoring of Rare, Threatened, and Endangered Species on Military Lands." The technical monitor was Phil Pierce, DAIM-ED-R.

The work was performed by the Natural Resource Assessment and Management Division (LL-N) of the Land Management Laboratory (LL), U.S. Army Construction Engineering Research Laboratories (USACERL). Stephen Demarais and Richard Hansen are affiliated with the Department of Range and Wildlife Management, Texas Tech University. The USACERL principal investigator was Dr. Clifford G. Rice. Dr. David J. Tazik is Acting Chief, CECER-LL-N; Dr. William D. Severinghaus is Operations Chief, CECER-LL. The USACERL technical editor was Gloria J. Wienke, Technical Resources.

Dr. Michael J. O'Connor is Director of USACERL. 


\section{Contents}

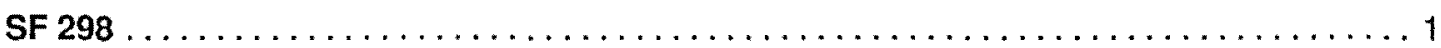

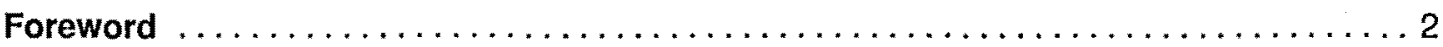

List of Figures and Tables $\ldots \ldots \ldots \ldots \ldots \ldots \ldots \ldots \ldots \ldots \ldots \ldots \ldots \ldots \ldots$

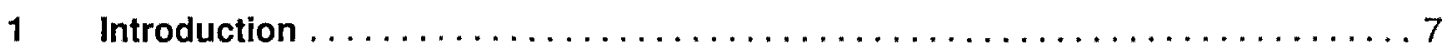

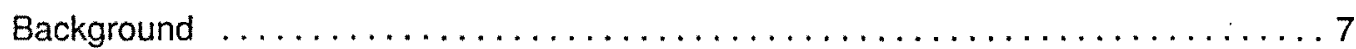

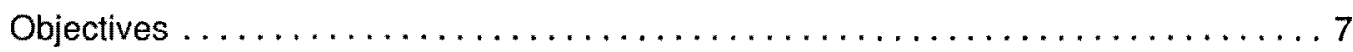

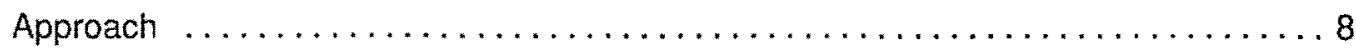

$2 \quad$ LCTA Methods $\ldots \ldots \ldots \ldots \ldots \ldots \ldots \ldots \ldots \ldots \ldots \ldots \ldots \ldots \ldots$

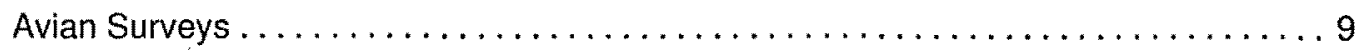

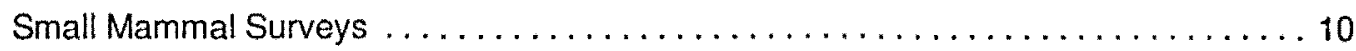

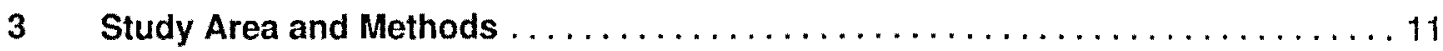

Avian Surveys . . . . . . . . . . . . . . . . . . . . . . . . . . 12

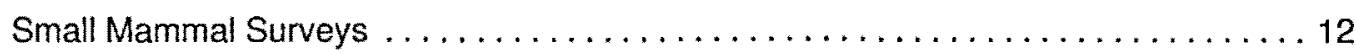

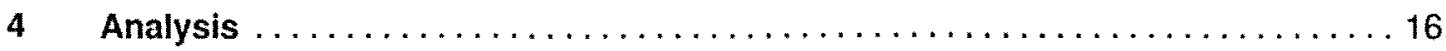

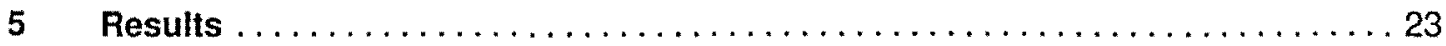

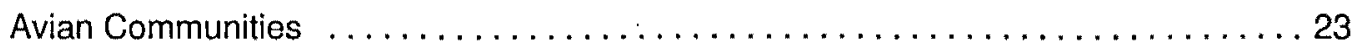

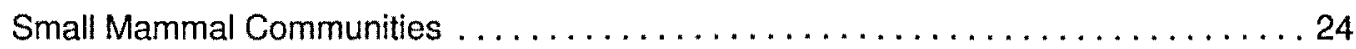

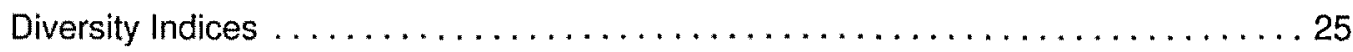

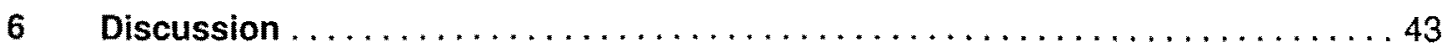

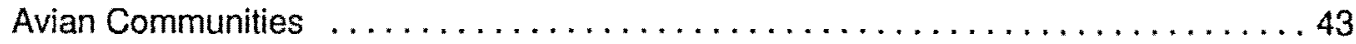

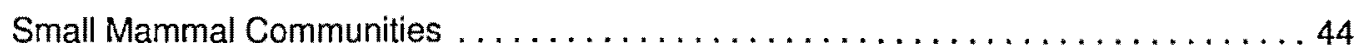

Diversity Indices . . . . . . . . . . . . . . . . . . . . . . . . . 44

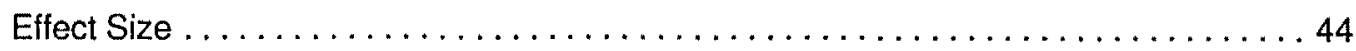

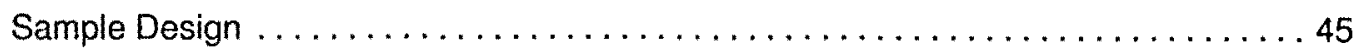

7 Conclusions and Recommendations $\ldots \ldots \ldots \ldots \ldots \ldots \ldots \ldots \ldots \ldots$

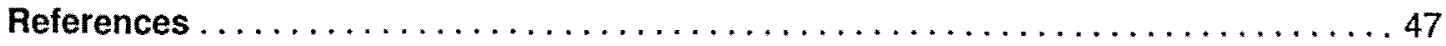




\section{List of Figures and Tables}

\section{Figures}

Locations of study sites $\ldots \ldots \ldots \ldots \ldots \ldots \ldots \ldots \ldots \ldots \ldots \ldots \ldots \ldots \ldots \ldots$

3 Configuration of small mammal trapping arrays at Camp Florence

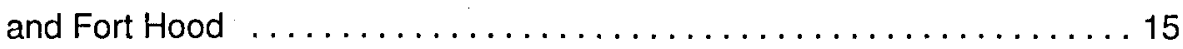

Schematic representation of community comparisons by species composition

Power to detect differences in avian community composition at Camp

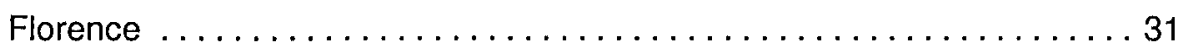

$7 \quad$ Power to detect differences in avian community composition at Camp Florence, Fort Hood, and Fort Bliss $\ldots \ldots \ldots \ldots \ldots \ldots \ldots \ldots \ldots \ldots \ldots \ldots \ldots$

Power to detect differences in avian community composition at Fort Hood 33

9 Power to detect differences in avian community composition at Fort Bliss

Power to detect differences in small mammal community composition at Camp Florence and Fort Hood

Power to detect differences in small mammal community composition at Camp Florence . . . . . . . . . . . . . . . . . . . . 37

12 Power to detect differences in small mammal community composition

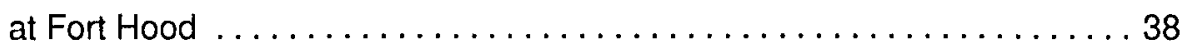

Power to detect differences in small mammal community composition at Fort Bliss 
14 Power to detect differences in avian community diversity at

Fort Bliss . . . . . . . . . . . . . . . . . . . 39

15 Power to detect differences in small mammal community diversity at Camp Florence (not pooled over days) $\ldots \ldots \ldots \ldots \ldots \ldots \ldots \ldots$

16 Power to detect differences in small mammal community diversity at Camp Florence (pooled over days) $\ldots \ldots \ldots \ldots \ldots \ldots \ldots \ldots \ldots \ldots$

17 Comparison of power to detect differences in small mammal community diversity found in two habitats at Camp Florence using community composition and the best diversity index $\ldots \ldots \ldots \ldots 42$

Tables

Diversity indices used for comparisions in LCTA methods

evaluation 21

Similarity indices used for comparisons in LCTA methods evaluation

Avian species observed during surveys on Camp Florence, $A Z, 3$ through 19 March 1993

Avian species observed during surveys on Fort Hood, TX, 17 June through 12 July 1993 28

Avian species observed during surveys on Fort Bliss, TX, 5 May through 8 June 1993 and 3 through 23 May 1994 . .

Mammal species captured during surveys on Camp Florence, $A Z, 8$ September through 15 October 1993

Mammal species captured during surveys on Fort Hood, TX, 26 October through 3 December 1993

Mammal species captured during surveys on Fort Bliss, TX, 25 April through 20 May 1993 . 
11 Statistical power associated with diversity index values of small

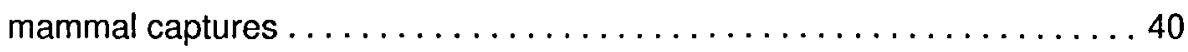

12 Relative increase in power by increasing sampling by number of sites

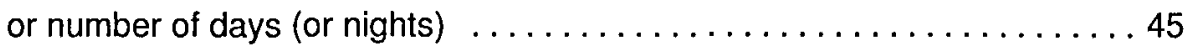




\section{Introduction}

\section{Background}

Monitoring ecological systems is necessary to measure and assess change. The U.S. Army's Land Condition Trend Analysis (LCTA) program was established to inventory and monitor ecological systems on Army lands using a standardized methodology (Diersing, Shaw, and Tazik 1992, Tazik et al. 1992). Information obtained using LCTA is designed to assist installation resource managers in meeting multiple-use demands (Diersing, Shaw, and Tazik 1992, Tazik et al. 1992).

The ability to detect changes in ecological systems depends on monitoring methods, appropriate experimental design, and analytical approaches. LCTA data have been collected on various installations, and analysis and interpretation is underway (Price et al. 1995). Unfortunately, few studies have evaluated whether LCTA methods are effective in detecting ecological change (Rice, Demarais, and Hansen in press). A useful approach in evaluating the suitability of LCTA methods for assessing ecological change is through power analysis.

Statistical power is the probability of detecting a specified level of difference between variables using statistical analysis (Cohen 1988; Lipsey 1990). Lack of power resulting from inefficient monitoring methods and analysis can result in the failure to identify ecological change when it occurs (Type II Error). This could result in recommendations that are inappropriate for meeting natural resource management goals on Army lands. Therefore, statistical power analysis assesses the monitoring program's suitability for making land management recommendations.

\section{Objectives}

The objectives of this study were to evaluate, using power analysis, bird and small mammal inventory and monitoring protocols on Army lands in the southwestern United States. Specifically, the study addressed three aspects of bird and small mammal community survey design: field sampling techniques; sampling design; and analytical approaches. 


\section{Approach}

Statistical power analysis (Cohen 1988; Lipsey 1990) was used to evaluate various field survey methods and analytical approaches of the LCTA program. Monitoring methods are designed to detect ecological change over time. In this study, differences in vertebrate community composition between two habitats served as a surrogate for differences in a given habitat over time. Power analysis was used to contrast composition (number of individuals of each species) between respective avian and small mammal communities occurring in two distinct habitats at each of three Army installations. Also, four commonly used diversity indices were evaluated for their utility in measuring ecological differences. 


\section{LCTA Methods}

LCTA plot inventory field methods were presented by Tazik et al. (1992) from which the following procedures are summarized. LCTA surveys are conducted on permanent plots at each Army installation. Location of plots are chosen using an automated site selection process to ensure objectivity, randomness, and representation. Plots are allocated proportionally to land cover types on each installation as delineated by SPOT (Systeme Probatoire por l'Observation de la Terre) satellite imagery, soil surveys, and the GRASS (Geographic Resources Analysis Support System) geographic information system. The number of plots depends on the size of the installation and the variation in land cover and soil types. Approximately one plot per 200 ha, with a maximum of 200 plots on large installations, is recommended. The standard LCTA plot is $100 \times 6 \mathrm{~m}$. A $100-\mathrm{m}$ transect is established along the longitudinal axis of the plot, in which various biotic and abiotic factors are measured. Data collection occurs in three phases, initial inventory, short-term monitoring, and long-term monitoring. After the initial inventory phase, plots are monitored on a regular basis (usually annually) for changes in land use, such as surface disturbance, ground cover, canopy cover, and floral and faunal composition.

\section{Avian Surveys}

A modified point-count transect survey is used to census avifauna. At each survey plot, an observer takes 6 minutes to walk the 100-m transect and record all birds detected by sight or sound within $100 \mathrm{~m}$ of the transect line. The observer remains stationary at the end of the transect for 8 minutes and records all birds detected. The observer then takes 6 minutes to return to the starting point, again recording all birds detected within $100 \mathrm{~m}$ of the transect. At each plot, avian surveys are conducted twice per survey period; once in the first four hours of daylight and once in the last four hours of daylight. Surveys are conducted during the seasonal peak in avian activity at each installation. 


\section{Small Mammal Surveys}

For each plot, a trap array is constructed of 40 Museum Special traps and 10 rat snap traps. Museum Special traps are placed $7.5 \mathrm{~m}$ apart along two lines $15 \mathrm{~m}$ from, and parallel to the $100 \mathrm{~m}$ LCTA transect. The rat traps are positioned 1 to $2 \mathrm{~m}$ to the interior of the Museum Special traps; the first rat trap is placed coincident to the third Museum Special trap and thereafter spaced $30 \mathrm{~m}$ apart. Traps are baited with a peanut butter-rolled oats mixture and are set for two consecutive nights to obtain a total of 100 trap-nights per plot. All captures are removed from the survey plots for later identification. Trapping is conducted during the seasonal peak in small mammal activity at each installation. 


\section{Study Area and Methods}

Field trials were conducted at three installations, Camp Florence, AZ; Fort Hood, TX; and Fort Bliss, NM-TX (Figure $1^{*}$ ). At each installation, two habitats were selected for conducting avian and small mammal surveys. Habitats were chosen on the basis of observed differences in plant species associations.

Habitats selected at Camp Florence were creosote and cactus. Creosote bush (Larrea tridentata) was the dominant species in the creosote habitat, followed by cholla (Opuntia spp.) and velvet mesquite (Prosopis juliflora). The cactus habitat was composed of a combination of cactus, trees, and shrubs. Saguaro (Carnegiea gigantea), yellow palo-verde (Parkinsonia microphyllum), desert ironwood (Olneya tesota), and chollas were the primary plant species of this habitat.

At Fort Hood, the two habitats were forest and savannah. Forest habitat was composed primarily of live oak (Quercus fusiformis) and cedar (Juniperus ashei). Understory vegetation included redbud (Cercis canadensis), possum-haw (Ilex decidua), elbow-bush (Forestiera pubescens), and bunch grasses. Savannah habitat contained scattered cedars and several grass species including little bluestem (Schizachyrium scoparium), Indian grass (Sorghastrum avenaceum), and sideoats grama (Bouteloua curtipendula).

Upland and arroyo habitats were selected at Fort Bliss. White-thorn acacia (Acacia constricta) and ephedra (Ephedra spp.) were the primary shrub species in the upland habitat. Grasses included sideoats grama, black grama (Bouteloua eriopoda), muhlys (Muhlenbergia spp.), and three-awns (Aristida spp.). The arroyo habitat was associated with xeroriparian zones scattered around the study area. Shrubs included littleleaf sumac (Rhus microphylla), tarbush (Flourencia cernua), and fourwing saltbush (Atriplex canescens). Grasses in arroyo habitats included tobosa (Hilaria mutica), alkali sacaton (Sporobolus airoides), saltgrass (Distichlis spicata), and blue grama (Bouteloua gracilis).

* Figures and tables are presented at the end of each chapter. 


\section{Avian Surveys}

For surveys at Camp Florence and Fort Hood, four sites were located within each of the two habitats where LCTA surveys (walk-in, point count, and walk-out) were carried out (Figure 2). Seven survey combinations derived from the original LCTAtype survey method were examined. These were: (1) walk-in portion of survey, (2) walk-out portion of survey, (3) point count survey, (4) walk-in and walk-out portion of survey, (5) walk-in portion and point count survey, (6) walk-out portion of survey and point count survey, and (7) all three survey methods combined (LCTA standard survey). Surveys were conducted on 8 days at each site. Avian surveys were conducted at Camp Florence between 3 and 19 March 1993 and at Fort Hood between 17 June and 12 July 1993.

At Fort Bliss, each of the two habitats had six replicate sites. Avian survey methods at each site included eight point count surveys and one LCTA-type survey and were arranged along the arroyo. Surveys were conducted for 4 days on each site from 5 May to 8 June 1993 and 3 to 23 May 1994.

\section{Small Mammal Surveys}

For surveys at Camp Florence and Fort Hood, the four sites selected for avian surveys were also used for small mammal surveys. Surveys consisted of three different trapping arrays located on each site (Figure 2). These included the Museum Special and rat snap trap array (standard LCTA trap array), Sherman live trap and rat snap trap array, and Sherman live trap and pitfall array (Figure 3). Pitfall drift fences were constructed from roof flashing and were approximately 41 $\mathrm{cm}$ high and $10 \mathrm{~m}$ long; buckets were $22 \mathrm{~cm}$ in diameter and $31 \mathrm{~cm}$ deep. Trapping arrays were monitored for 8 nights. Surveys were conducted at Camp Florence between 8 September and 15 October 1993 and at Fort Hood between 26 October and 3 December 1993.

At Fort Bliss, each of the two habitats had five replicate sites. Trapping was conducted with a 90-trap array using Sherman live traps set for 4 consecutive nights. Traps were set $20 \mathrm{~m}$ apart along three 300 -m rows; spacing between each row was $10 \mathrm{~m}$. Trapping was conducted between 25 April and 20 May 1993. 


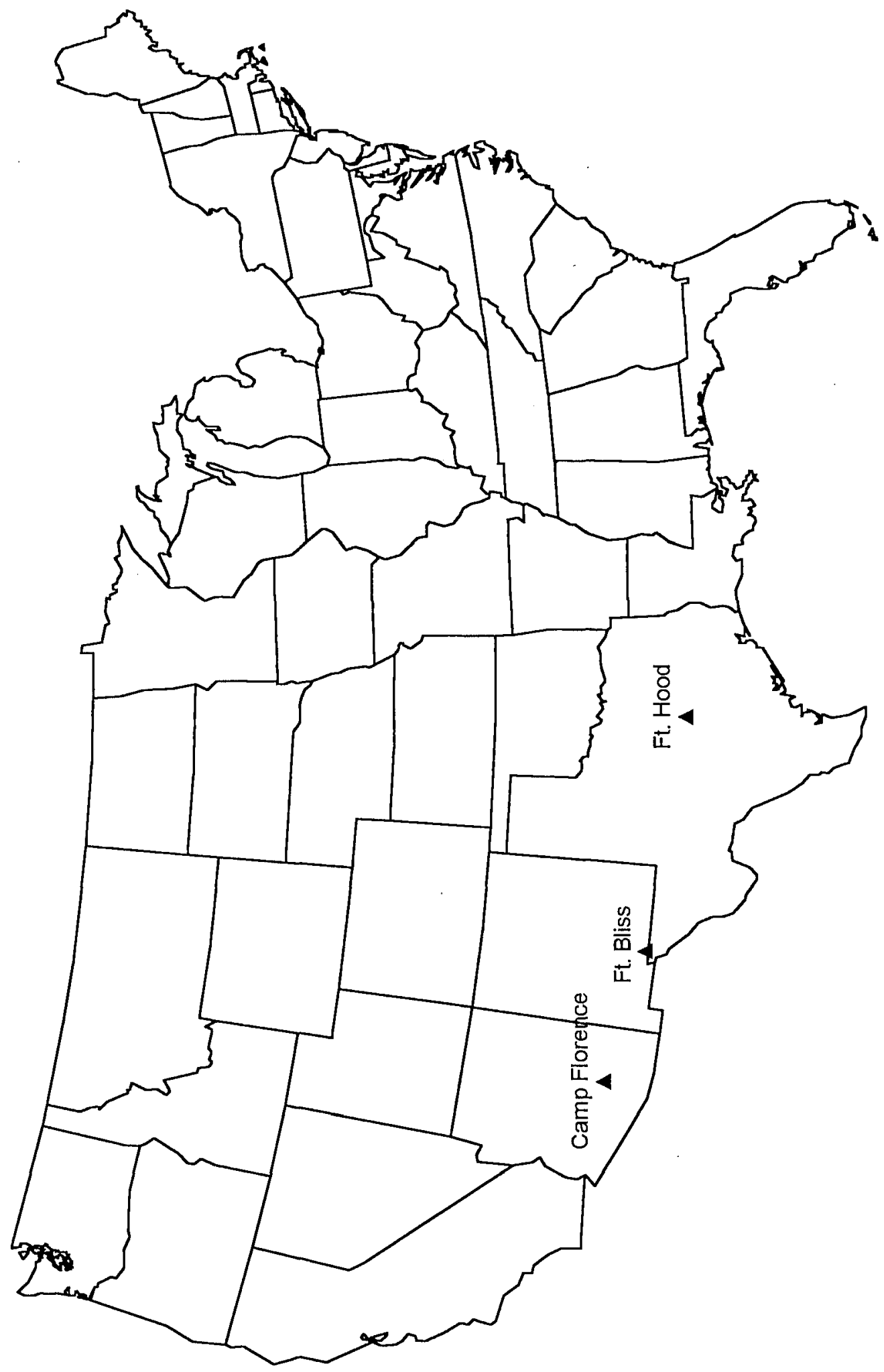




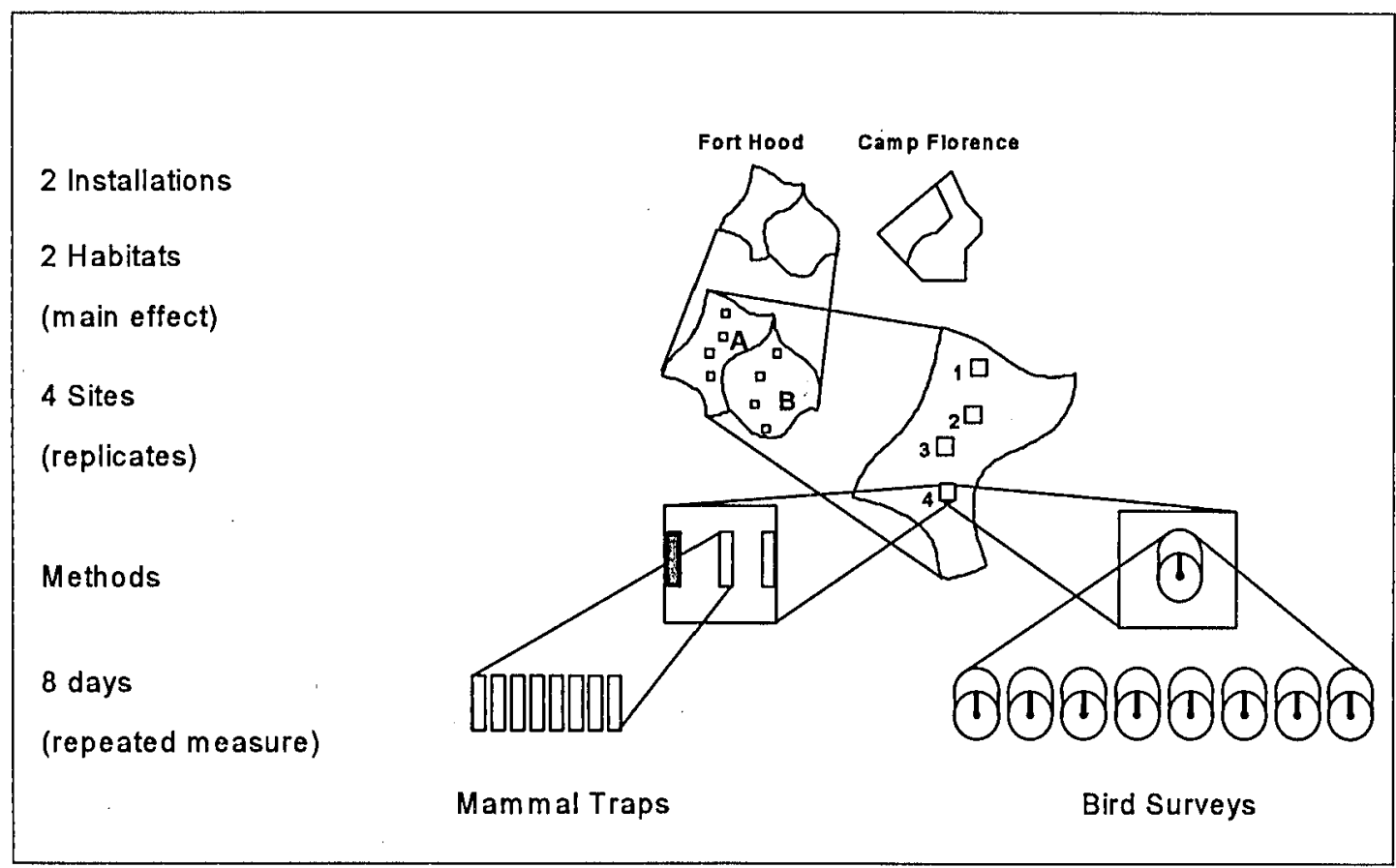

Figure 2. Schematic layout of field sampling. 


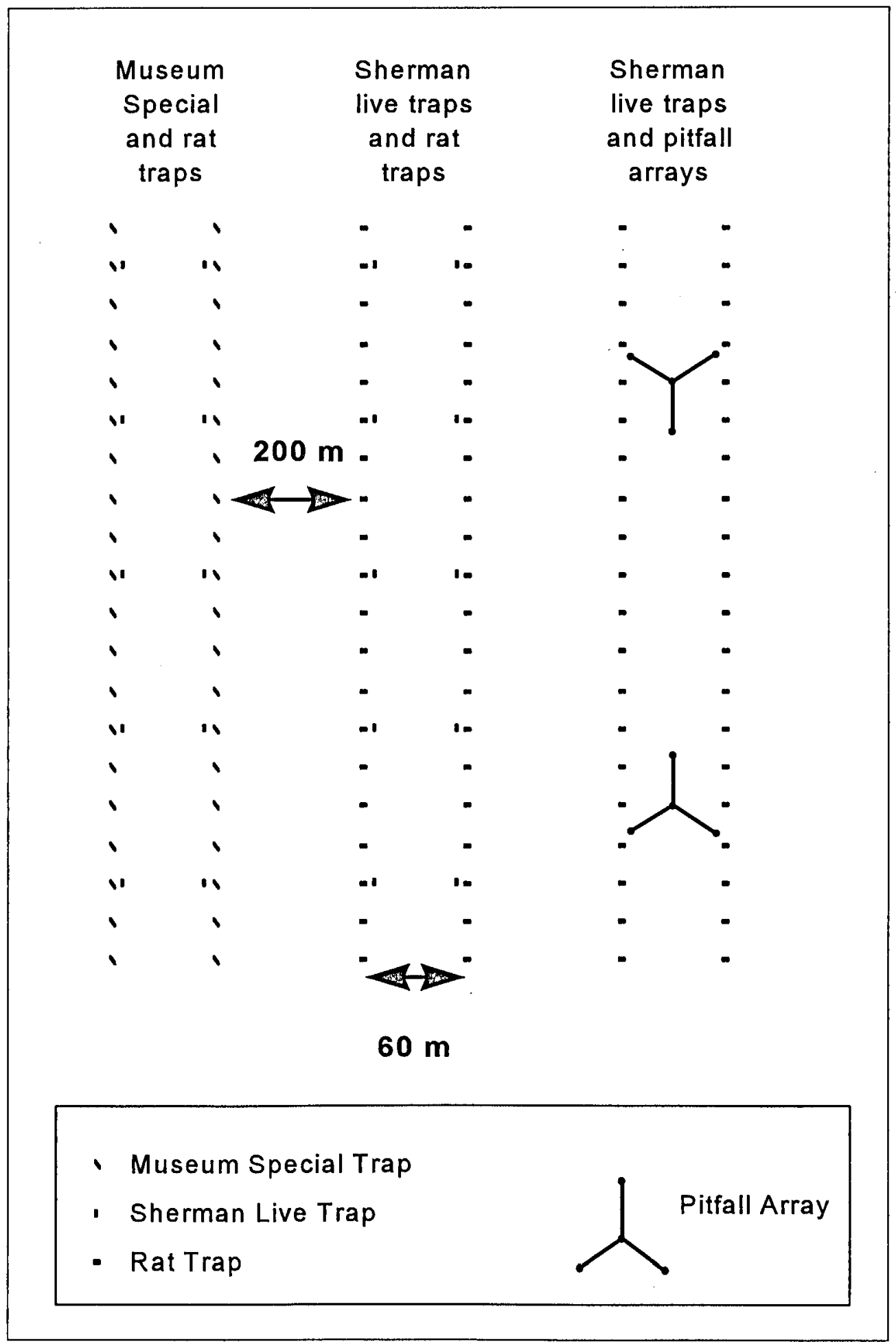

Figure 3. Configuration of small mammal trapping arrays at Camp Florence and Fort Hood. 


\section{Analysis}

LCTA methods do not stipulate specific analytical approaches (Tazik et al. 1992). To avoid biases related to survey methods, and because the primary objective was to detect differences between communities rather than estimating their exact composition, the avian and small mammal communities (actual numbers observed, detected, or captured) were analyzed. Data collected from these surveys were used in two ways: (1) as a direct measure of community composition and (2) for calculating diversity indices. Data from each installation were analyzed separately for two reasons. First, the primary objective was to determine if community differences could be detected between habitats within installations and not among installations and second, the effect sizes, which are determined by the differences between communities, were not standardized among installations.

A repeated measures analysis of variance (ANOVA) design was used in the analysis. The multivariate approach to repeated measures ANOVA is severely affected by missing values (Dunn and Clark 1974), and it was not used for this reason. Missing values were from missed surveys (due to poor weather conditions, equipment failure, etc.) and results for which it was impossible to calculate diversity index values (see Chapter 6, Discussion).

The alternative, a nested univariate approach to ANOVA with repeated measures (Norusis 1993) was used. In this design, the response variable was the number of individuals of each species recorded, sites were the experimental unit, repeated measures were days of surveying, and in the case of combined bird survey assessments, survey method also was a repeated measure.

In assessing community differences, two types of effect were considered; the habitat main effect, and the species-habitat interaction affect. The first assesses the degree of change in number of individuals for all species together, whereas the second assesses the relative number of individuals for each species between the communities (Figure 4).

For the habitat main effect, the test statistic was the ratio of the mean square for habitat to the mean square for site within habitat. The statistical test of interest for the community composition analysis was the ratio of the mean square for the 
habitat-species interaction and the mean square for species by site within habitat. A significant interaction indicated that the number of individuals of each species in one habitat was different from the number of individuals of each species in the other habitat (i.e., vertebrate communities were different, Figure 4; Rice, Demarais, and Hansen in press). Power values were generated using the power option of SPSS (Norusis 1993).

Typically, ANOVA is used to evaluate the probability $(P)$ that sample means are different. In this study, the assumption was that there were differences in faunal communities between differing habitats; interest was in the probability of detecting that difference, or statistical power $(1-\beta)$. Power is a function of the significance level chosen for the statistical test $(\alpha)$, sample size $(n)$, variability in the data, and the effect size (ES). Since the power of statistical tests using each survey method was of interest, power was estimated for each survey method. Including survey methods as a treatment effect in the ANOVA models would have determined whether various survey methods produced statistically significant results, but would not have provided information needed to assess which field methods yielded the most powerful tests.

There is no consensus on what is considered adequate power, but $0.80(\beta=0.20)$ is commonly used in research (Cohen 1988; Lipsey 1990). Determination of the necessary statistical power is a management decision, but for discussion in this study, a power level of 0.80 was considered adequate. For all analyses, $\alpha=0.05$ was used.

In power analysis, the effect of sampling intensity on power usually can be estimated with power tables, power curves, or formulas after a test is completed (Cohen 1988; Lipsey 1990). In this study, sampling intensity for each of the two habitats was determined by the number of survey sites and number of survey days. Consequently, it could not be determined if the estimated change in power due to a different sampling intensity was associated with a comparable change in the number of sites surveyed or the number of days sampled. An alternate approach was used to calculate power using subsamples of the complete data set that represented differing numbers of sites and survey days. Because there were numerous possible permutations for most of these subsamples, power was calculated for five randomly selected permutations for each combination of sites and days. Power for that particular combination of sites and days was estimated as the mean of the five subsamples; generated values were graphed and compared visually (see Chapter 5 , Results). For avian surveys, days were selected randomly because they were assumed to be unbiased by chronology. Small mammal data were treated as a chronological string (e.g., five sample days were always one through five) due to the 
effects of sampling duration on mammal trapping (Renzulli, Flowers, and Tamarin 1980; Bury and Corn 1987).

Because power is closely related to sample size, contour graphs illustrating power as a function of both number of sites and number of days surveyed can be expected to have a concave shape, as a plot of $\mathrm{n}$ does (where $\mathrm{n}=$ days $\times$ sites). Greater effect on power from either sites or days is evidence by differences from the basic pattern (Figure 5).

Diversity was measured for avian and small mammal communities for each of the two habitat types on the three installations. Four common diversity indices were calculated (Table 1): species richness (S) (McIntosh 1967), reciprocal of Simpson's dominance index $\left(d_{s}\right)$ (Simpson 1949), Shannon's index ( $H$ ) (Shannon and Weaver 1949), and Fisher's $\alpha$ (Fisher, Corbet, and Williams 1943). Power analysis for diversity indices was based on the habitat main effect on bird or small mammal species composition.

Four similarity indices were used (Table 2) to evaluate community composition and structure between the two habitats at each of the three installations and relate these findings to effect size and diversity index values. The percent similarity index $(P S)$ (Pielou 1975) evaluated the similarity in the number of species in both habitats (independent of co-occurrence). The Jaccard index $\left(C_{j}\right)$ (Jaccard 1908) was used to determine the similarity of species co-occurrence between both habitats. Two quantitative indices (includes both presence and abundance data) were used: the Sorenson quantitative index $\left(C_{N}\right)$ (Bray and Curtis 1957) and the Morisita-Horn index $\left(C_{M H}\right)$ (Horn 1966). The Morisita-Horn index was selected because it is less affected by sample size and species diversity than other quantitative similarity indices (Wolda 1981). 
Habitat Effect (neglible species effect, no interaction)

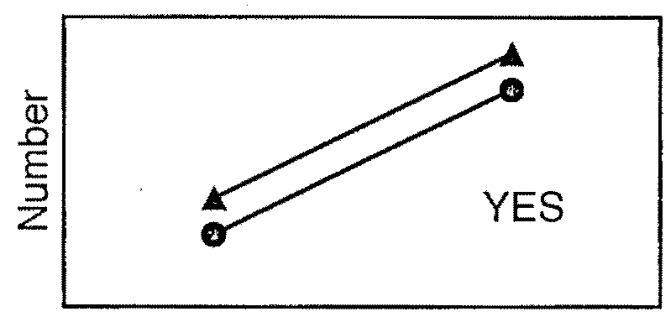

A

Interaction of Effect

(no species effect, no habitat effect)

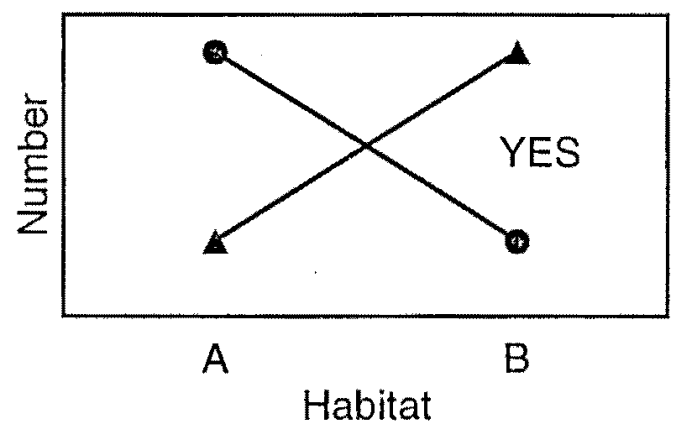

Species Effect

(no habitat effect, no interaction)

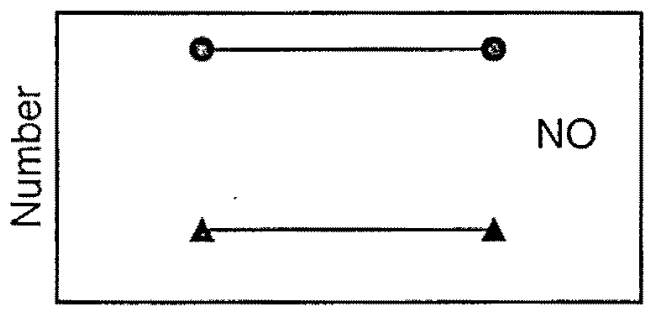

A

B

Habitat Effect \& Interaction (neglible species effect)

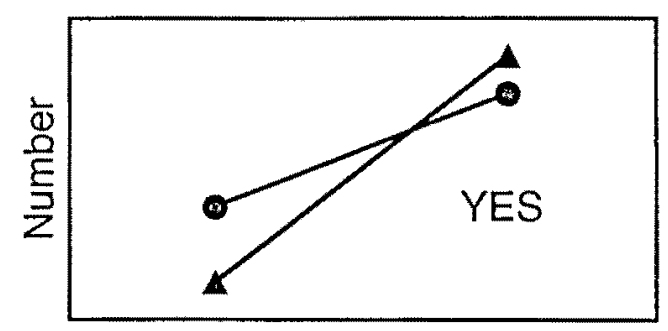

A

Habitat

$$
\rightarrow \text { Species } 1 \text { - } \rightarrow \text { Species } 2
$$

YES indicates effects that a monitoring program should detect.

Figure 4. Schematic representation of community comparisons by specles composition. 

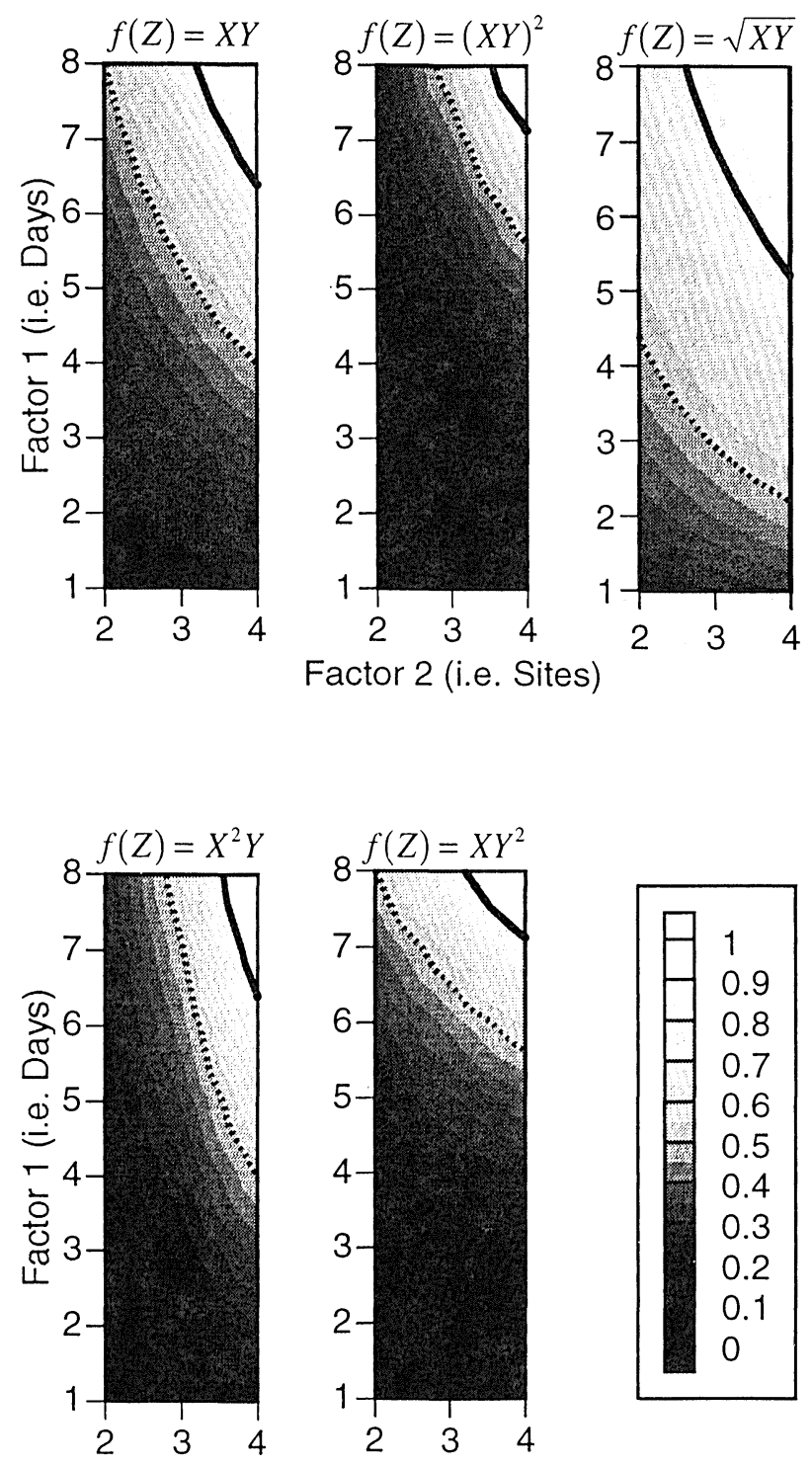

Factor 2 (i.e. Sites)

Figure 5. Hypothetical contour graphs of power. 
Table 1. Diversity indices used for comparisions in LCTA methods evaluation.

\begin{tabular}{|c|c|c|c|}
\hline Index & Symbol & Formula & Reference \\
\hline Species Richness & $S$ & $\mathrm{~S}$ & Mclntosh 1967 \\
\hline $\begin{array}{l}\text { Reciprocal of } \\
\text { Simpson's } \\
\text { Dominance }\end{array}$ & $\mathrm{d}_{\mathrm{s}}$ & $\mathrm{d}_{\mathrm{s}}=\frac{\mathrm{N}(\mathrm{N}-1)}{\sum \mathrm{n}_{\mathrm{i}}\left(\mathrm{n}_{\mathrm{i}}-1\right)}$ & Simpson 1949 \\
\hline Shannon's & $\mathrm{H}^{\prime}$ & $H^{\prime}=\sum \frac{n_{i}}{N} \log \frac{n_{i}}{N}$ & Shannon and Weaver 1949 \\
\hline Fisher's $\alpha$ & $\alpha$ & $\begin{array}{l}\text { simultaneously } \\
S=-\alpha \log _{e}(1-x) \\
\text { and } \\
N=\frac{\alpha x}{1-x} \\
\text { for } \alpha \text { and } x\end{array}$ & Fisher et al. 1943 \\
\hline
\end{tabular}


Table 2. Similarity indices used for comparisons in LCTA methods evaluation.

\begin{tabular}{|c|c|c|c|}
\hline Index & Symbol & Formula & Reference \\
\hline Percent Similarity & $P S$ & $\mathrm{PS}=200 \sum_{\mathrm{i}=1}^{\mathrm{S}} \min \left(\mathrm{P}_{\mathrm{iX}}, \mathrm{P}_{\mathrm{iY}}\right)$ & Pielou 1975 \\
\hline Jaccard & $\mathrm{C}_{\mathrm{j}}$ & $C_{j}=\frac{j}{a+b+j}$ & Jaccard 1908 \\
\hline Sorenson quantitative & $\mathrm{C}_{\mathrm{N}}$ & $C_{j}=\frac{2 j n}{a N+b N}$ & $\begin{array}{l}\text { Bray and Curtis } \\
1957\end{array}$ \\
\hline Morista-Horn & $\mathrm{C}_{\mathrm{MH}}$ & $\begin{array}{c}\mathrm{C}_{\mathrm{MH}}=\frac{2 \sum\left[\left(\mathrm{an}_{\mathrm{i}}\right)\left(\mathrm{bn}_{\mathrm{i}}\right)\right]}{(\mathrm{da}+\mathrm{db})[(\mathrm{aN})(\mathrm{bN})]} \\
\mathrm{da}=\frac{\sum \mathrm{an}_{\mathrm{i}}^{2}}{\mathrm{aN}^{2}} \text { and } \mathrm{db}=\frac{\sum \mathrm{bn}_{\mathrm{i}}^{2}}{\mathrm{bN}^{2}}\end{array}$ & Horn 1966 \\
\hline \multicolumn{4}{|c|}{$\begin{array}{l}P_{i x} \text { and } P_{i \gamma} \text { are quantities of species } i \text { in habitats } \mathrm{X} \text { and } \mathrm{Y} \text { as proportions of the quantities of all } S \text { species in the two } \\
\text { habitats combined. } \\
j=\text { number of species common to both habitats } \mathrm{A} \text { and } \mathrm{B} \text {. } \\
a=\text { number of species in habitat } \mathrm{A} \text {. } \\
b=\text { number of species in habitat } \mathrm{B} \text {. } \\
\text { jn }=\text { sum of the lower of the two abundances recorded for species found in both habitats. } \\
a N=\text { number of individuals in habitat } \mathrm{A} \text {. } \\
b N=\text { number of individuals in habitat } \mathrm{B} \text {. } \\
a n_{1}=\text { number of individuals of the th species in habitat } \mathrm{A} \text {. } \\
b n_{i}=\text { number of individuals of the ith species in habitat } \mathrm{B} \text {. }\end{array}$} \\
\hline
\end{tabular}




\section{Results}

\section{Avian Communities}

Avian species found during the surveys are listed in Tables 3 through 5. Avian communities at Camp Florence and Fort Hood showed little difference in the number of species between habitats, as reflected by relatively high PS values (Table 6). High values for Jacard's index indicated that a large proportion of species co-occurred in both habitats at these two installations (Table 6). However, larger differences were observed between habitats at Fort Bliss. Substantially more bird species were found in the arroyo habitat ( 45 species) than were found in the upland habitat (21 species); only 18 species were found in both habitats (Table 5 ).

At Camp Florence and Fort Hood, high values of the Sorensen and Morisita-Horn indices (Table 6) suggest relative evenness in avian communities between the two habitats. Fort Bliss had lower values of both indices (Table 6). This suggested substantial difference in avian community structure (number of species and number of individuals of species) between the two habitats at Fort Bliss.

Habitat main effects yielded less power than species-habitat interactions for detecting community differences. Power values for the habitat main effect and species-habitat interaction, respectively, were 0.23 and 0.84 at Camp Florence, 0.11 and 0.85 at Fort Hood, and 0.53 and 0.88 at Fort Bliss.

At Camp Florence, the point count surveys yielded the lowest power of all survey methods (Figure 6 ). The walk-in survey yielded adequate power $(\geq 0.80)$ with four or more survey days. The walk-out survey yielded adequate power with three or more days, and consistently showed higher power than the walk-in survey. Combinations of survey methods also yielded high power at three or more survey days and had higher power levels than point surveys (Figure 6). Power contours, generated from all survey methods combined, indicated that power increased with an increase in the number of survey sites and survey days (Figure 7). At Camp Florence, sufficient power was obtained with two survey sites and seven survey days, three sites and three days, and four sites and three days (Figure 7). At Fort Hood, sufficient power was obtained with three survey sites and four days; and five survey sites and three days. 
At Fort Hood, none of the avian survey methods or combinations yielded adequate power (Figure 8), and most of the survey methods or combinations did not yield increased power with increasing survey days. Only the point count and walk-in combination yielded power values slightly above 0.70 , but only for survey days two through five and on the eighth survey day. Power values generated from the walk-in and walk-out combination actually declined with increasing survey days. Surface contours of statistical power, generated with all survey methods combined, indicated that with combinations of both survey sites and survey days, statistical power reached 0.50 but failed to attain adequate power (Figure 7). Additionally, there was no observable pattern in which power increased due to concomitant increases in the number of sites or survey days.

Power associated with avian surveys on Fort Bliss indicated that both the point count method and the combined methods (LCTA-type survey) had sufficient power (Figure 9). Both increased in power with increasing number of survey days. Power for point counts were above 0.80 with three survey days, and for all combinations of survey methods, sufficient power was reached on the second survey day (Figure 9). Surface contours of statistical power using both sites and days indicated that three sites and four survey days, and five sites and three days achieved adequate power (Figure 7).

\section{Small Mammal Communities}

Species found during small mammal surveys are listed in Tables 7 through 9 . At Camp Florence, high percent similarity indicated that both habitats contained similar numbers of species and high Jaccard's index values indicated that a high proportion of the same species occurred in both habitats (Table 6). These results were similar to findings at Fort Bliss (Table 6). At Fort Hood, both these values were low (Table 6). This indicated that the number of species between habitats varied and that few species occurred in both habitats, respectively.

Both Sorenson and Morisita-Horn indices varied dramatically at each installation (Table 6). The small number of species found in both habitat types at each installation may have biased Sorenson index values. Values of the Morisita-Horn index suggested a lack of evenness between small mammal communities, particularly at Camp Florence and Fort Hood. Further examination of data collected at these two installations found one or two species numerically dominated in a particular habitat (Tables 7 and 8). 
For small mammal data collected at Camp Florence and Fort Hood, power to detect habitat main effects was extremely low compared to species-habitat interactive effects. Power values for the habitat main effect and species-habitat interaction were 0.12 and 0.96 at Camp Florence, 0.07 and 0.83 at Fort Hood, and 0.85 and 0.99 at Fort Bliss, respectively.

At Camp Florence, power was consistently high $(>0.95)$ for the Sherman/rat trap and Sherman/pitfall trap arrays (Figure 10). High power was obtained even with only one night of trapping using these methods. Although power was initially lower for the Museum Special/rat trap array, adequate power was obtained with only two nights trapping and achieved similar power values to the other methods on the fifth night (Figure 10). Power contours indicated that the Sherman/rat trap array achieved adequate power with two sites and two nights of trapping, and three sites and one night of trapping (Figure 11). For the Sherman/pitfall trap array, adequate power was obtained with three sites and two nights of trapping, or four sites and one night of trapping. The Museum Special/rat trap array had the lowest power of the three trap arrays, but adequate power was obtained with three sites and five trap nights, or four sites and two trap nights (Figure 11).

At Fort Hood, the Museum Special/rat trap array yielded low power $(<0.20)$, even after eight nights of trapping (Figure 10). Sufficient power for the Sherman/rat trap array was attained on the fifth night of trapping. Power with the Sherman/pitfall array was highly variable. Power values increased to over 0.8 on the fifth trap night, then declined (Figure 10). Statistical power contours generated for the Sherman/rat trap array and the Sherman/pitfall trap array indicated that sufficient power was obtained with four sites and five nights trapping, but power contours appeared to be too variable to elucidate any trend associated with increasing sites or sampling nights (Figure 12). For the Museum Special/rat trap array, no combination of sites and days yielded power values above 0.5 (Figure 12).

At Fort Bliss, all combinations of sites and days obtained sufficient power (Figure 13). Sufficient power was obtained with only two survey sites and two nights of trapping using the 90-trap array of Sherman live traps.

\section{Diversity Indices}

Diversity indices were calculated for avian communities found within each habitat for each of the three installations (Table 10). Analysis of avian diversity indices among survey sites or days at Camp Florence and Fort Hood was not possible due to missing values and resulting redundancies in ANOVA design matrices. Data from 
Fort Bliss could be examined by survey sites for data collected during 1993 and 1994, but similar problems to those found at the other installations precluded use of Fisher's $\alpha$. Each of the remaining three diversity indices $\left(S, d_{s}, H^{\prime}\right.$ produced consistently similar results in describing avian diversity at Fort Bliss (Figure 14). Power of diversity indices varied between years. During 1993, none of the three indices attained satisfactory power even with up to six survey sites, yet during 1994, all three indices yielded high power with three or more survey sites (Figure 14).

For small mammal communities, diversity indices were generated for both habitats at each of the three installations (Table 10). Statistical power associated with the analysis of small mammal diversity indices was low at all installations (Table 11).

Several general trends were evident when data from Camp Florence were examined by trap array types and diversity indices. When diversity indices were calculated for each sample, power was low and never reached satisfactory levels (Figure 15). When captures were pooled over nights, trapping methods yielded greater power (Figure 16). Observed differences were due more to sampling method than to index. However, power was still generally low for diversity indices calculated from data collected using the Sherman and pitfall trap array, and the Museum Special and rat trap array. Only the Sherman/rat trap array with diversity indices $d_{s}, H^{\prime}$, and Fisher's $\alpha$, achieved adequate power (Figure 16). Both $d_{s}$ and $H^{\prime}$ attained sufficient power at five nights. Whereas, Fisher's $\alpha$ attained sufficient power on the seventh night (Figure 16). The combination of trap array and diversity index that yielded the best power values was the Sherman/rat trap array and $d_{s}$ (Figure 17). The low number of captures at Fort Hood precluded making these kinds of comparisons. 
Table 3. Avian species observed during surveys on Camp Florence, AZ, 3 through 19 March 1993.

\begin{tabular}{|l|l|r|r|r|}
\hline \multicolumn{2}{|l|}{} & \multicolumn{2}{|c|}{ Habitat } & \\
\hline Common Name & Scientific Name & Cactus & Creosote & Total \\
\hline Cactus Wren & Campylorhynchus brunneicapillus & 443 & 371 & 814 \\
\hline Curve-billed Thrasher & Toxostoma curvirostris & 168 & 135 & 303 \\
\hline House Finch & Carpodacus mexicanus & 170 & 123 & 293 \\
\hline Gila Woodpecker & Melanerpes uropygiale & 185 & 101 & 286 \\
\hline Ash-throated Flycatcher & Myiarchus cinerascens & 118 & 122 & 240 \\
\hline Verdin & Auriparus flaviceps & 44 & 46 & 90 \\
\hline Black-tailed Gnatcatcher & Polioptila melanura & 40 & 43 & 83 \\
\hline Gambel's Quail & Callipepla gambelii & 45 & 31 & 76 \\
\hline Black-throated Sparrow & Amphispiza bilineata & 43 & 21 & 64 \\
\hline Mourning Dove & Zenaida macroura & 29 & 30 & 59 \\
\hline Northern Mockingbird & Mimus polyglottos & 27 & 14 & 41 \\
\hline Phainopepla & Phainopepla nitens & 23 & 10 & 33 \\
\hline Brown-headed Cowbird & Molothrus ater & 19 & 11 & 30 \\
\hline Common Flicker & Colaptes auratus & 16 & 13 & 29 \\
\hline Brown-crested Flycatcher & Myiarchus tyrannulus & 20 & 7 & 27 \\
\hline Northern Cardinal & Cardinalis cardinalis & 8 & 10 & 18 \\
\hline Red-tailed Hawk & Buteo jamaicensis & 4 & 10 & 14 \\
\hline White-winged Dove & Zenaida asiatica & 10 & 2 & 12 \\
\hline Bendire's Thrasher & Toxostoma bendirei & 3 & 4 & 7 \\
\hline American Kestrel & Falco sparverius & 0 & 5 & 5 \\
\hline Ladder-backed Woodpecker & Picoides scalaris & 0 & 4 & 4 \\
\hline Northern Oriole & Icterus galbula & 3 & 0 & 3 \\
\hline Brown Towhee & Pipilo fuscus & 0 & 0 & 3 \\
\hline Olive-sided Flycatcher & Contopus borealis & 0 & 0 & 2 \\
\hline Loggerhead Shrike & Lanius ludovicianus & 1 & 2 & 2 \\
\hline European Starling & Sturnus vulgaris & 2 & 2 \\
\hline Lucy's Warbler & Vermivora luciae & 2 & 2 \\
\hline Wilson's Warbler & Wilsonia pusilla & 0 & 2 \\
\hline Western Tanager & Piranga ludoviciana & 1 & 1 \\
\hline Black-throated Gray Warbler & Dendroica nigrescens & 1122 & 2546 \\
\hline Totals & & & \\
\hline & & 0 & 24 & 2 \\
\hline
\end{tabular}


Table 4. Avian species observed during surveys on Fort Hood, TX, 17 June through 12 July 1993.

\begin{tabular}{|c|c|c|c|c|}
\hline & & $\mathrm{Hab}$ & & \\
\hline Common Name & Scientific Name & Savannah & Forest & Total \\
\hline Northern Cardinal & Cardinalis cardinalis & 320 & 226 & 546 \\
\hline Northern Mockingbird & Mimus polyglottos & 224 & 258 & 482 \\
\hline Mourning Dove & Zenaida macroura & 116 & 182 & 298 \\
\hline Northern Bobwhite & Colinus virginianus & 115 & 151 & 266 \\
\hline Garolina Wren & Thryothorus ludovicianus & 109 & 138 & 247 \\
\hline Lark Sparrow & Chondestes grammacus & 87 & 159 & 246 \\
\hline Brown-headed Cowbird & Molothrus ater & 121 & 54 & 175 \\
\hline Yellow-billed Cuckoo & Coccyzus americanus & 61 & 41 & 102 \\
\hline Tufted Titmouse & Parus bicolor & 38 & 47 & 85 \\
\hline Blue-gray Gnatcatcher & Polioptila caerulea & 16 & 54 & 70 \\
\hline Carolina Chickadee & Parus carolinensis & 42 & 21 & 63 \\
\hline Eastern Meadowlark & Sturnella magna & 41 & 22 & 63 \\
\hline Common Nighthawk & Chordeiles minor & 31 & 27 & 58 \\
\hline Ruby-throated Hummingbird & Archilochus colubris & 33 & 14 & 47 \\
\hline White-eyed Vireo & Vireo griseus & 20 & 11 & 31 \\
\hline Chimney Swift & Chaetura pelagica & 28 & 1 & 29 \\
\hline Painted Bunting & Passerina ciris & 15 & 10 & 25 \\
\hline Turkey Vulture & Cathartes aura & 16 & 3 & 19 \\
\hline Barn Swallow & Hirundo rustica & 17 & 1 & 18 \\
\hline Cliff Swallow & Hirundo pyrrhonota & 5 & 7 & 12 \\
\hline Ladder-backed Woodpecker & Picoides scalaris & 7 & 0 & 7 \\
\hline Golden-cheeked Warbler & Dendroica chrysoparia & 0 & 6 & 6 \\
\hline Black-capped Chickadee & Parus atricapillus & 0 & 6 & 6 \\
\hline Scissor-tailed Flycatcher & Tyrannus forficatus & 4 & 0 & 4 \\
\hline Red-tailed Hawk & Buteo jamaicensis & 2 & 0 & 2 \\
\hline Great Blue Heron & Ardea herodias & 1 & 1 & 2 \\
\hline Red-winged Blackbird & Agelaius phoeniceus & 0 & 2 & 2 \\
\hline Red-bellied Woodpecker & Melanerpes carolinus & 1 & 0 & 1 \\
\hline Killdeer & Charadrius vociferus & 0 & 1 & 1 \\
\hline Totals & & 1470 & 1443 & 2913 \\
\hline
\end{tabular}


Table 5. Avian species observed during surveys on Fort Bliss, TX, 5 May through 8 June 1993 and 3 through 23 May 1994.

\begin{tabular}{|c|c|c|c|c|}
\hline \multirow[b]{2}{*}{ Common Name } & \multirow[b]{2}{*}{ Scientific Name } & \multicolumn{2}{|c|}{ Habltat } & \multirow[b]{2}{*}{ Total } \\
\hline & & Arroyo & Upland & \\
\hline Black-throated Sparrow & Amphispiza bilineata & 166 & 162 & 328 \\
\hline Northern Mockingbird & Mimus polyglottos & 137 & 19 & 156 \\
\hline Mourning Dove & Zenaida macroura & 124 & 29 & 153 \\
\hline House Finch & Carpodacus mexicanus & 93 & 14 & 107 \\
\hline Eastern Meadowark & Sturnella magna & 37 & 68 & 105 \\
\hline Western Kingbird & Tyrannus verticalis & 66 & 14 & 80 \\
\hline Scott's Oriole & Icterus parisorum & 60 & 14 & 74 \\
\hline Cassin's Sparrow & Aimophila cassinil & 28 & 32 & 60 \\
\hline Brown-headed Cowbird & Molothrus ater & 51 & 0 & 51 \\
\hline Ash-throated Flycatcher & Myiarchus cinerascens & 42 & 2 & 44 \\
\hline Lark Bunting & Calamospiza melanocorys & 40 & 4 & 44 \\
\hline Common Nighthawk & Chordeiles minor & 11 & 23 & 34 \\
\hline Horned Lark & Eremophila alpestris & 0 & 24 & 24 \\
\hline Brown Towhee & Pipilo fuscus & 15 & 1 & 16 \\
\hline Scaled Quail & Callipepla squamata & 15 & 0 & 15 \\
\hline Cactus Wren & Campylorhynchus brunneicapillus & 12 & 1 & 13 \\
\hline Blue Grosbeak & Guiraca caerulea & 12 & 0 & 12 \\
\hline Green-tailed Towhee & Pipilo chlorurus & 12 & 0 & 12 \\
\hline Lark Sparrow & Chondestes grammacus & 3 & 8 & 11 \\
\hline Loggerhead Shrike & Lanius ludovicianus & 9 & 2 & 11 \\
\hline Cassin's Kingbird & Tyrannus vociferans & 6 & 3 & 9 \\
\hline Crissal Thrasher & Toxostoma dorsale & 8 & 0 & 8 \\
\hline Brewer's Sparrow & Spizelia breweri & 7 & 0 & 7 \\
\hline Wilson's Warbler & Wilsonia pusilla & 7 & 0 & 7 \\
\hline Fufous-crowned Sparrow & Aimophila ruficeps & 2 & 3 & 5 \\
\hline Broad-tailed Hummingbird & Selasphorus platycercus & 1 & 3 & 4 \\
\hline Dusky Flycatcher & Empidonax oberholseri & 4 & 0 & 4 \\
\hline Ladder-backed Woodpecker & Picoides scalaris & 4 & 0 & 4 \\
\hline Virginia's Warbler & Vermivora virginiae & 4 & 0 & 4 \\
\hline Violet-green Swallow & Tachycineta thalassina & 3 & 0 & 3 \\
\hline Lesser Nighthawk & Chordeiles acutipennis & 0 & 2 & 2 \\
\hline Western Tanager & Piranga ludoviciana & 2 & 0 & 2 \\
\hline White-crowned Sparrow & Zonotrichia leucophrys & 2 & 0 & 2 \\
\hline Barn Swallow & Hirundo rustica & 1 & 0 & 1 \\
\hline Bell's Vireo & Vireo bellii & 1 & 0 & 1 \\
\hline Curve-billed Thrasher & Toxostoma curvirostre & 1 & 0 & 1 \\
\hline Gambel's Quail & Callipepla gambelii & 1 & 0 & 1 \\
\hline Greater Roadrunner & Geococcyx californianus & 1 & 0 & 1 \\
\hline Indigo Bunting & Passerina cyanea & 1 & 0 & 1 \\
\hline MacGillivray's Warbler & Oporornis tolmiei & 1 & 0 & 1 \\
\hline Red-tailed Hawk & Buteo jamaicensis & 1 & 0 & 1 \\
\hline Ruby-crowned Kinglet & Regulus calendula & 1 & 0 & 1 \\
\hline Sage Sparrow & Amphispiza belli & 1 & 0 & 1 \\
\hline Say's Phoebe & Sayornis saya & 1 & 0 & 1 \\
\hline Verdin & Auriparus flaviceps & 1 & 0 & 1 \\
\hline Western Meadowlark & Sturnella neglecta & 0 & 1 & 1 \\
\hline Western Wood-Pewee & Contopus sordidulus & 1 & 0 & 1 \\
\hline Yellow Warbler & Dendroica petechia & 1 & 0 & 1 \\
\hline Totals & & 997 & 429 & 1426 \\
\hline
\end{tabular}


Table 6. Similarity index values from avian and small mammal surveys.

\begin{tabular}{|c|c|c|c|c|}
\hline Index Value & Symbol & Camp Florence & Fort Hood & Fort Bliss \\
\hline \multicolumn{5}{|l|}{ Birds } \\
\hline Percent Similarity ${ }^{a}$ & $P S$ & 78 & 84 & 27 \\
\hline Jaccard $^{b}$ & ; & 0.63 & 0.72 & 0.37 \\
\hline Sorenson quantatitive & $\mathrm{C}_{\mathrm{N}}$ & 0.88 & 0.99 & 0.60 \\
\hline Morisita-Horn & $\mathrm{C}_{\mathrm{MH}}$ & 0.99 & 0.93 & 0.67 \\
\hline \multicolumn{5}{|l|}{ Mammals } \\
\hline Percent Similaritya & $P S$ & 90 & 50 & 100 \\
\hline Jaccard $^{\mathrm{b}}$ & $C$ & 0.82 & 0.25 & 0.75 \\
\hline Sorenson quantatitive & $\mathrm{C}_{\mathrm{N}}$ & 0.88 & 0.94 & 0.78 \\
\hline Morisita-Horn & $\mathrm{C}_{\mathrm{MH}}$ & 0.29 & 0.29 & 0.49 \\
\hline
\end{tabular}




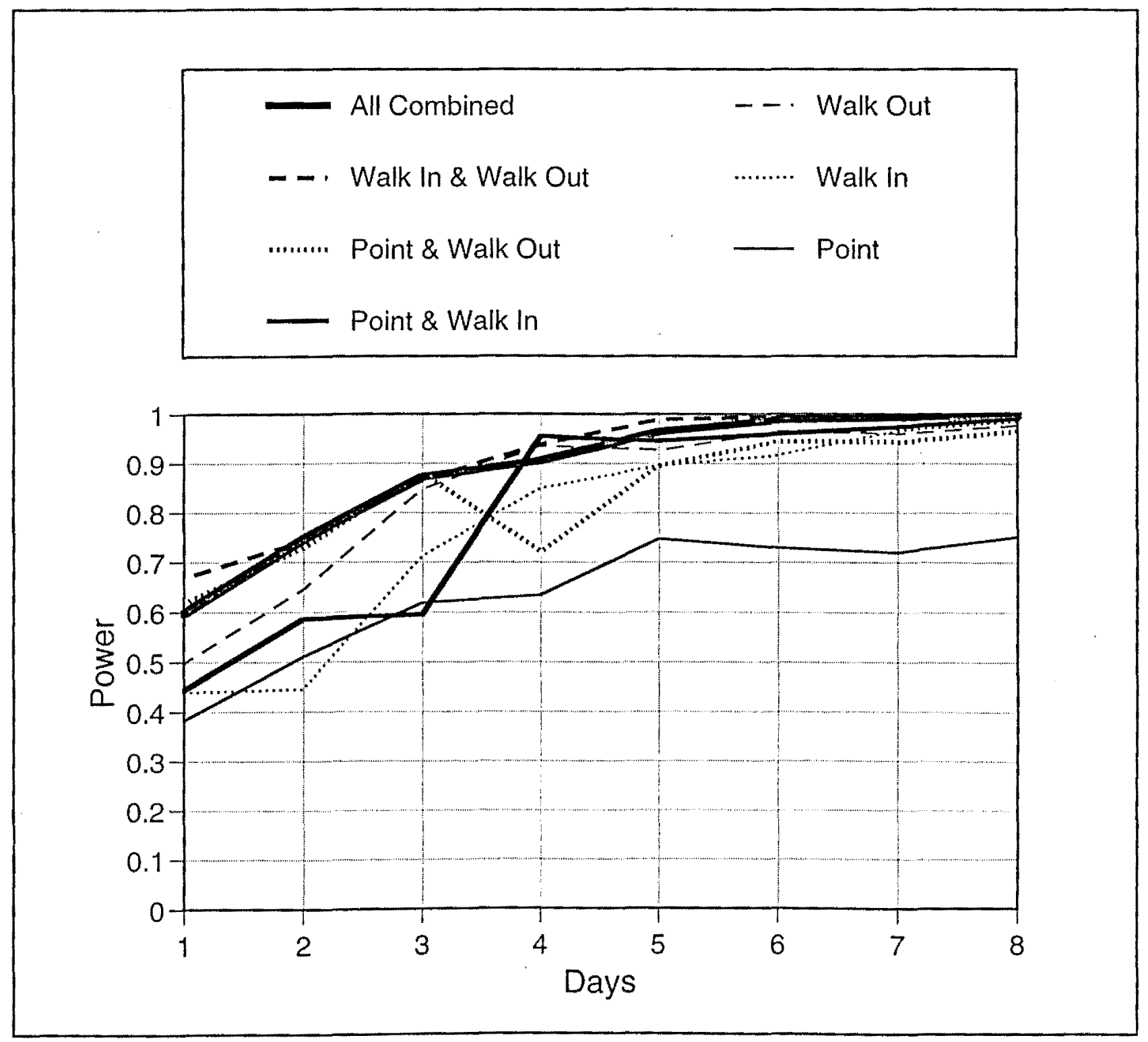

Figure 6. Power to detect differences in avian community composition at Camp Florence. 


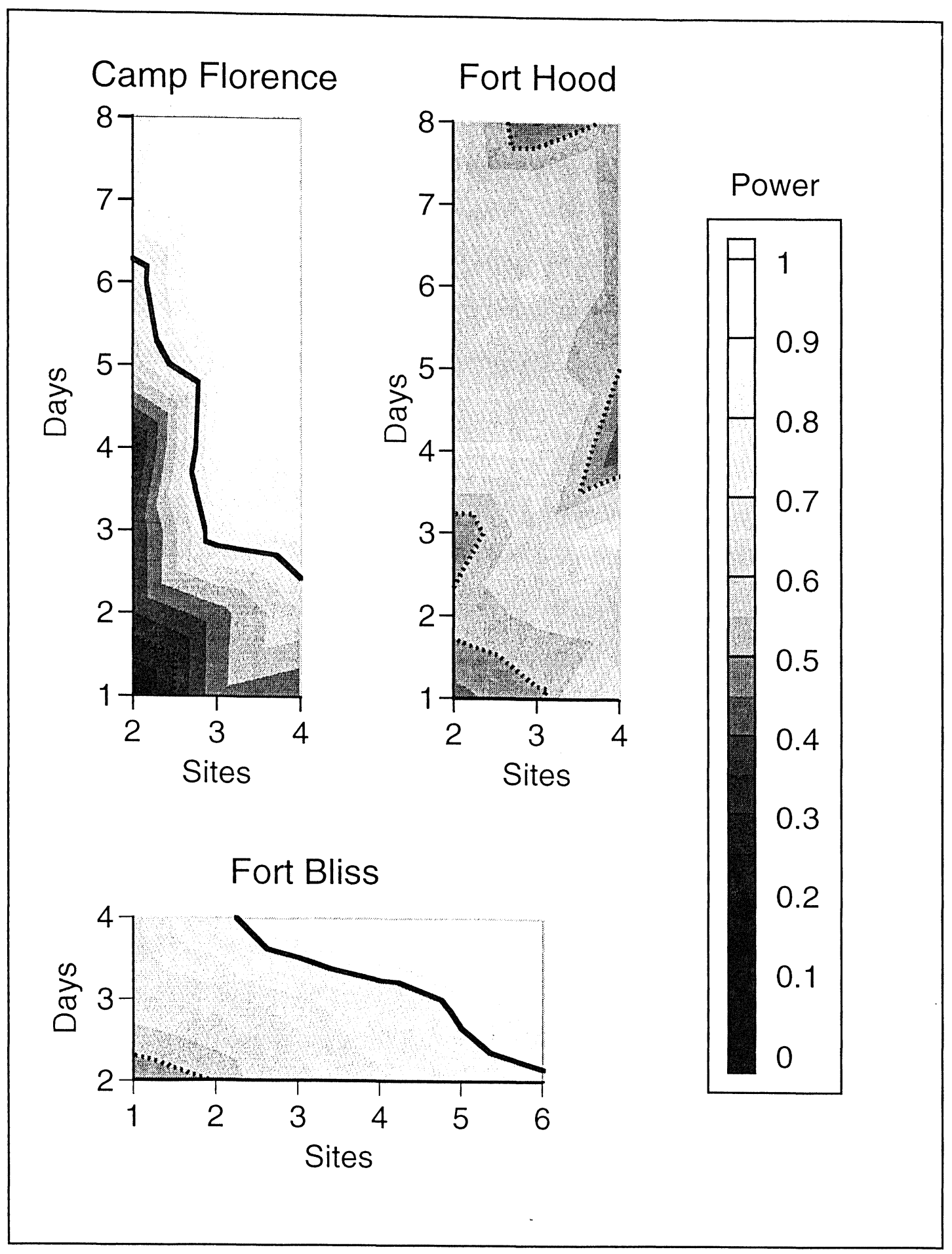

Figure 7. Power to detect differences in avian community composition at Camp Florence, Fort Hood, and Fort Bliss. 


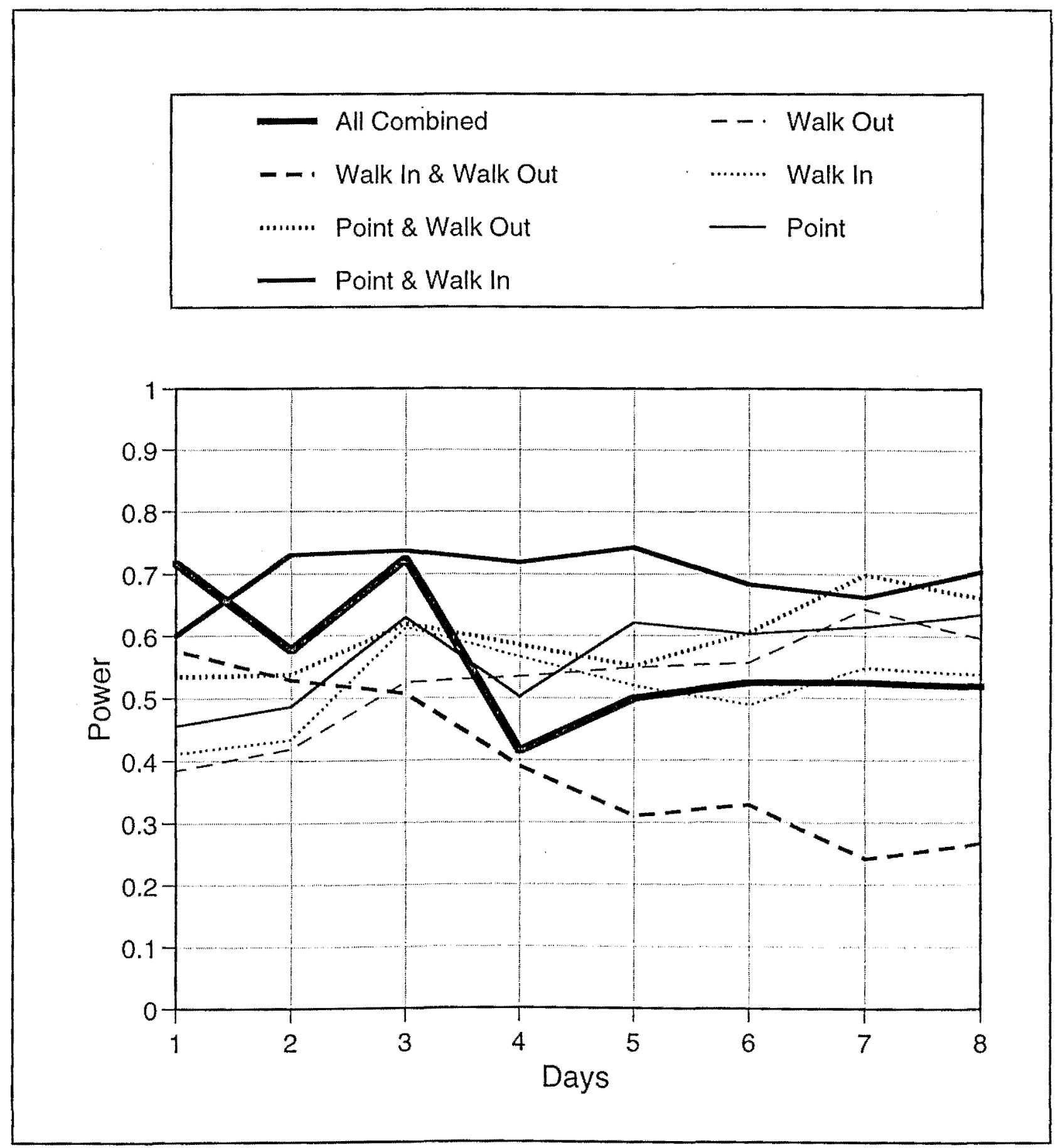

Figure 8. Power to detect differences in avian community composition at Fort Hood. 


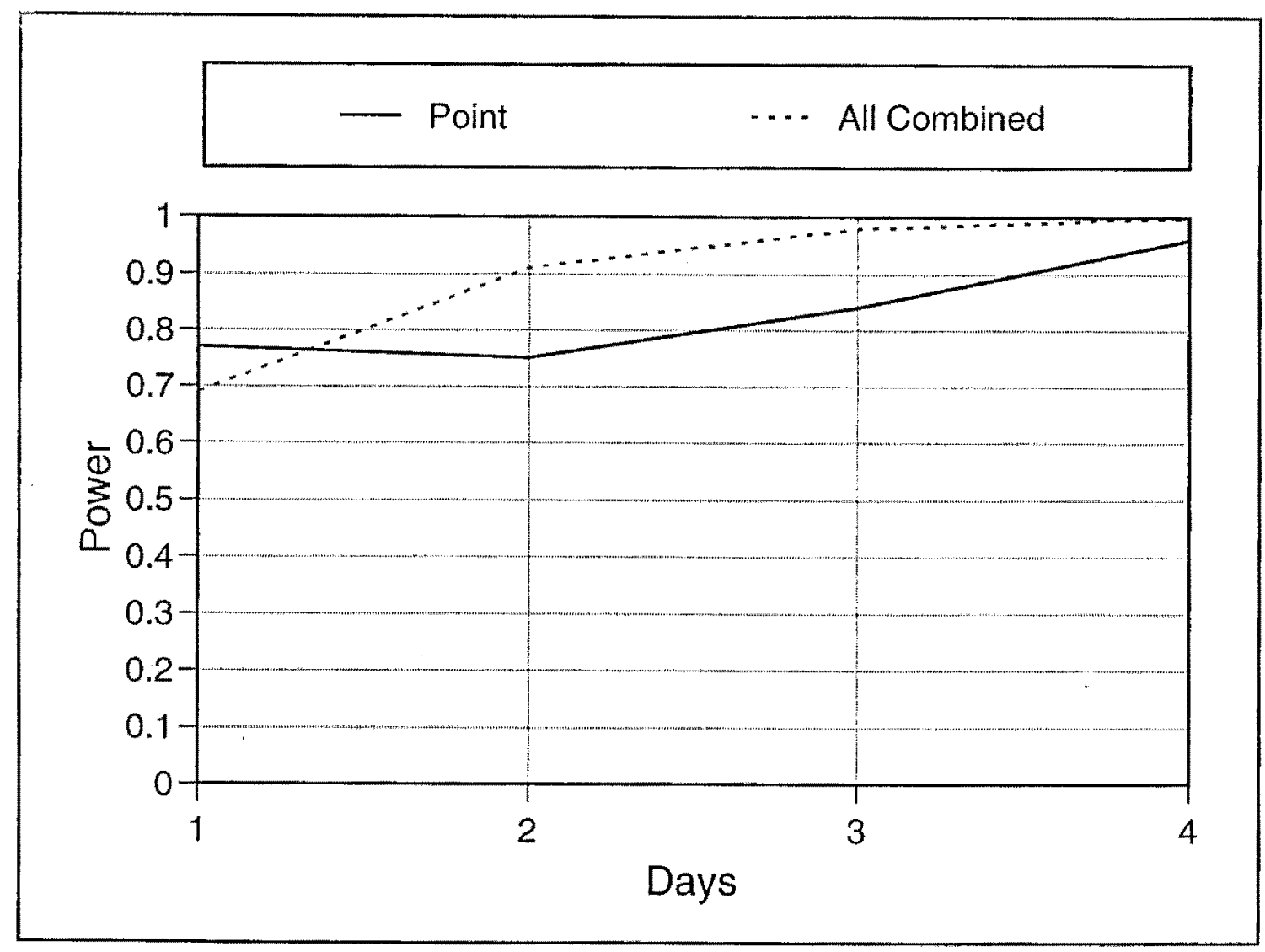

Figure 9. Power to detect differences in avian community composition at Fort Bliss.

Table 7. Mammal species captured during surveys on Camp Florence, AZ, 8 September through 15 October 1993.

\begin{tabular}{|l|l|r|r|r|}
\hline \multicolumn{2}{|c|}{} & \multicolumn{2}{|c|}{ Habitat } & \\
\hline Common Name & Scientific Name & Cactus & Creosote & Total \\
\hline Bailey's Pocket Mouse & Perognathus baileyi & 185 & 16 & 201 \\
\hline Silky Pocket Mouse & Perognathus flavus & 5 & 87 & 92 \\
\hline Desert Pocket Mouse & Perognathus penicillatus & 51 & 28 & 79 \\
\hline Merriam Kangaroo Rat & Dipodomys merriami & 25 & 51 & 76 \\
\hline Rock Pocket Mouse & Perognathus intermedius & 27 & 13 & 40 \\
\hline Arizona Pocket Mouse & Perognathus amplus & 4 & 33 & 37 \\
\hline Whitethroat Woodrat & Neotoma aibigula & 5 & 5 & 10 \\
\hline Bannertail Kangaroo Rat & Dipodomys spectabilis & 0 & 5 & 5 \\
\hline Harris Antelope Squirrel & Ammospermophilus harrisi & 2 & 2 & 4 \\
\hline Cactus Mouse & Peromyscus eremicus & 1 & 1 & 2 \\
\hline Arizona Cotton Rat & Sigmodon arizonae & 0 & 1 & 1 \\
\hline Totals & & 305 & 242 & 547 \\
\hline
\end{tabular}


Table 8. Mammal species captured during surveys on Fort Hood, TX, 26 October through 3 December 1993.

\begin{tabular}{|c|c|c|c|c|}
\hline & & Habit & & \\
\hline Common Name & Scientific Name & Savannah & Forest & Total \\
\hline White-footed Mouse & Peromyscus leucopus & 5 & 40 & 45 \\
\hline Texas Mouse & Peromyscus atwatteri & 8 & 9 & 17 \\
\hline Hispid Cotton Rat & Sigmodon hispidus & 16 & 0 & 16 \\
\hline Northern Pygmy Mouse & Baiomys taylori & 7 & 4 & 11 \\
\hline Fulvous Harvest Mouse & Reithrodontomys fulvescens & 7 & 0 & 7 \\
\hline Plains Harvest Mouse & Reithrodontomys montanus & 4 & 0 & 4 \\
\hline Least Shrew & Cryptotis parva & 2 & 0 & 2 \\
\hline Deer Mouse & Peromyscus maniculatus & 0 & 2 & 2 \\
\hline Silky Pocket Mouse & Perognathus flavus & 1 & 0 & 1 \\
\hline Hispid Pocket Mouse & Perognathus hispidus & 1 & 0 & 1 \\
\hline Brush Mouse & Peromyscus boylei & 0 & 1 & 1 \\
\hline Eastern Cottontail & Sylvilagus floridanus & 0 & 1 & 1 \\
\hline Totals & & 51 & 57 & 108 \\
\hline
\end{tabular}

Table 9. Mammal species captured during surveys on Fort Bliss, TX, 25 April through 20 May 1993.

\begin{tabular}{|l|l|r|r|r|}
\hline \multicolumn{2}{l}{} & \multicolumn{2}{|c|}{ Habitat } & \\
\hline Common Name & Scientific Name & Arroyo & Upland & Total \\
\hline White-footed Mouse & Peromyscus leucopus & 84 & 59 & 143 \\
\hline Merriam Kangaroo Rat & Dipodomys merriami & 15 & 118 & 133 \\
\hline Western harvest Mouse & Reithrodontomys megalotis & 64 & 45 & 109 \\
\hline Ord Kangaroo rat & Dipodomys ordi & 90 & 17 & 107 \\
\hline Plains Pocket Mouse & Perognathus flavescens & 5 & 93 & 98 \\
\hline Cactus Mouse & Peromyscus eremicus & 5 & 65 & 70 \\
\hline Deer Mouse & Peromyscus maniculatus & 28 & 23 & 51 \\
\hline Whitethroat Woodrat & Neotoma albigula & 6 & 38 & 44 \\
\hline Silky Pocket Mouse & Perognathus flavus & 14 & 29 & 43 \\
\hline Hispid Pocket Mouse & Perognathus hispidus & 9 & 18 & 27 \\
\hline Mearn's Grasshopper Mouse & Onychomys arenicola & 3 & 13 & 16 \\
\hline Rock Pocket Mouse & Perognathus intermedius & 5 & 6 & 11 \\
\hline Hispid Cotton Rat & Sigmodon hispidus & 6 & 0 & 6 \\
\hline Southern Plains Woodrat & Neotoma micropus & 5 & 0 & 5 \\
\hline Bannertail Kangaroo Rat & Dipodomys spectabilis & 0 & 1 & 1 \\
\hline Northern Grasshopper Mouse & Onychomys leucogaster & 0 & 1 & 1 \\
\hline Totals & & 339 & 526 & 865 \\
\hline
\end{tabular}




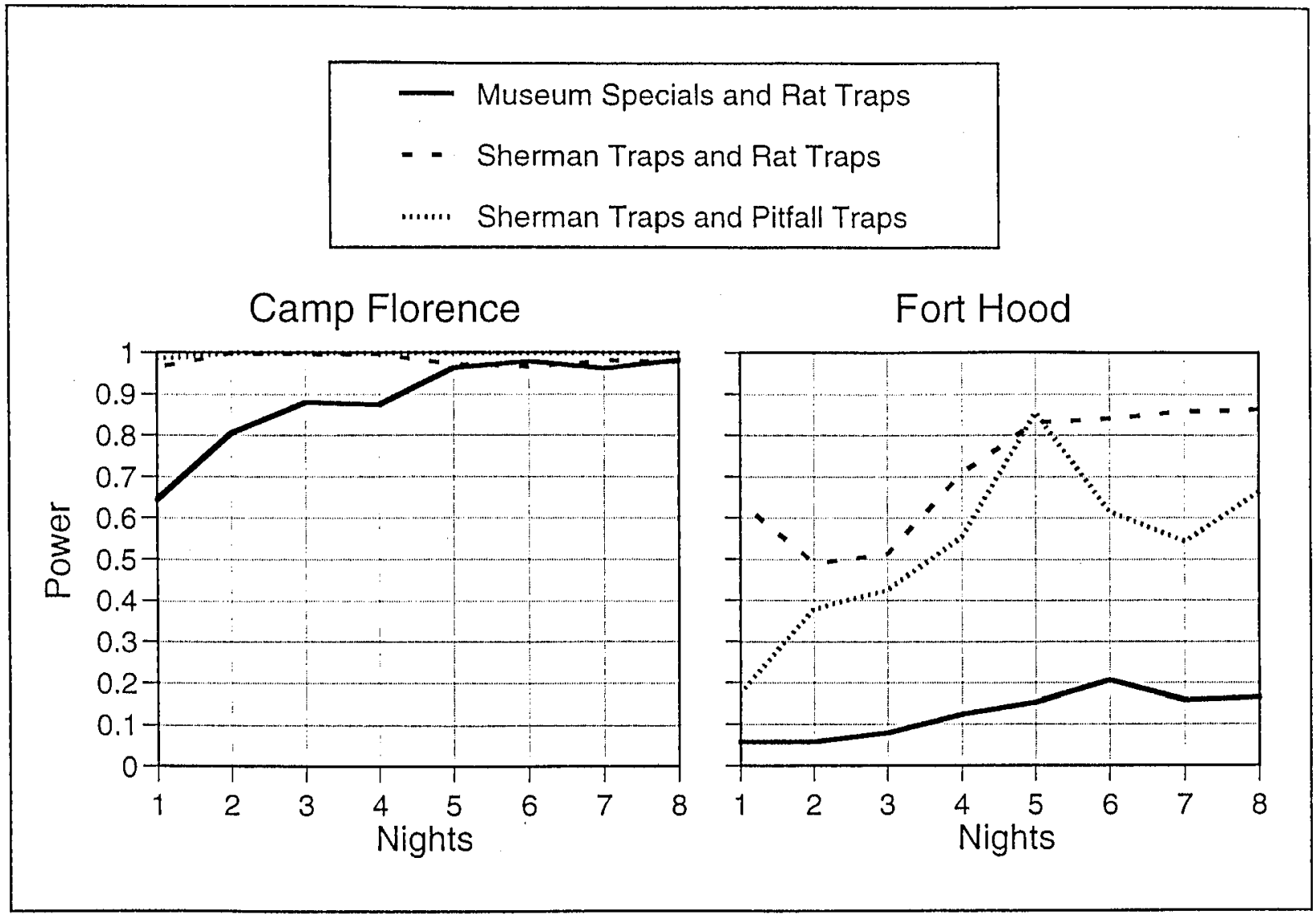

Figure 10. Power to detect differences in small mammal community composition at Camp Florence and Fort Hood. 


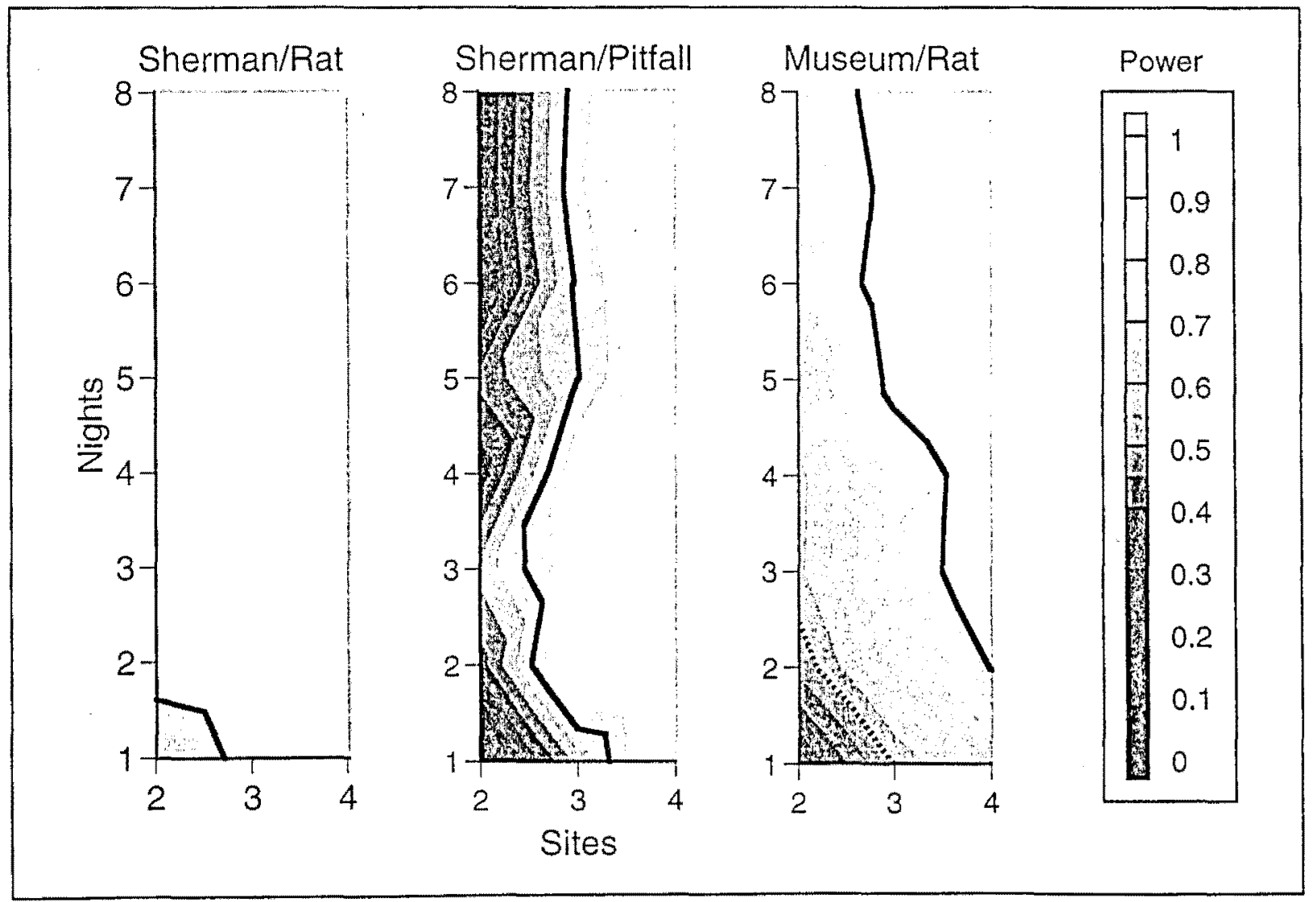

Figure 11. Power to detect differences in small mammal community composition at Camp Florence. 


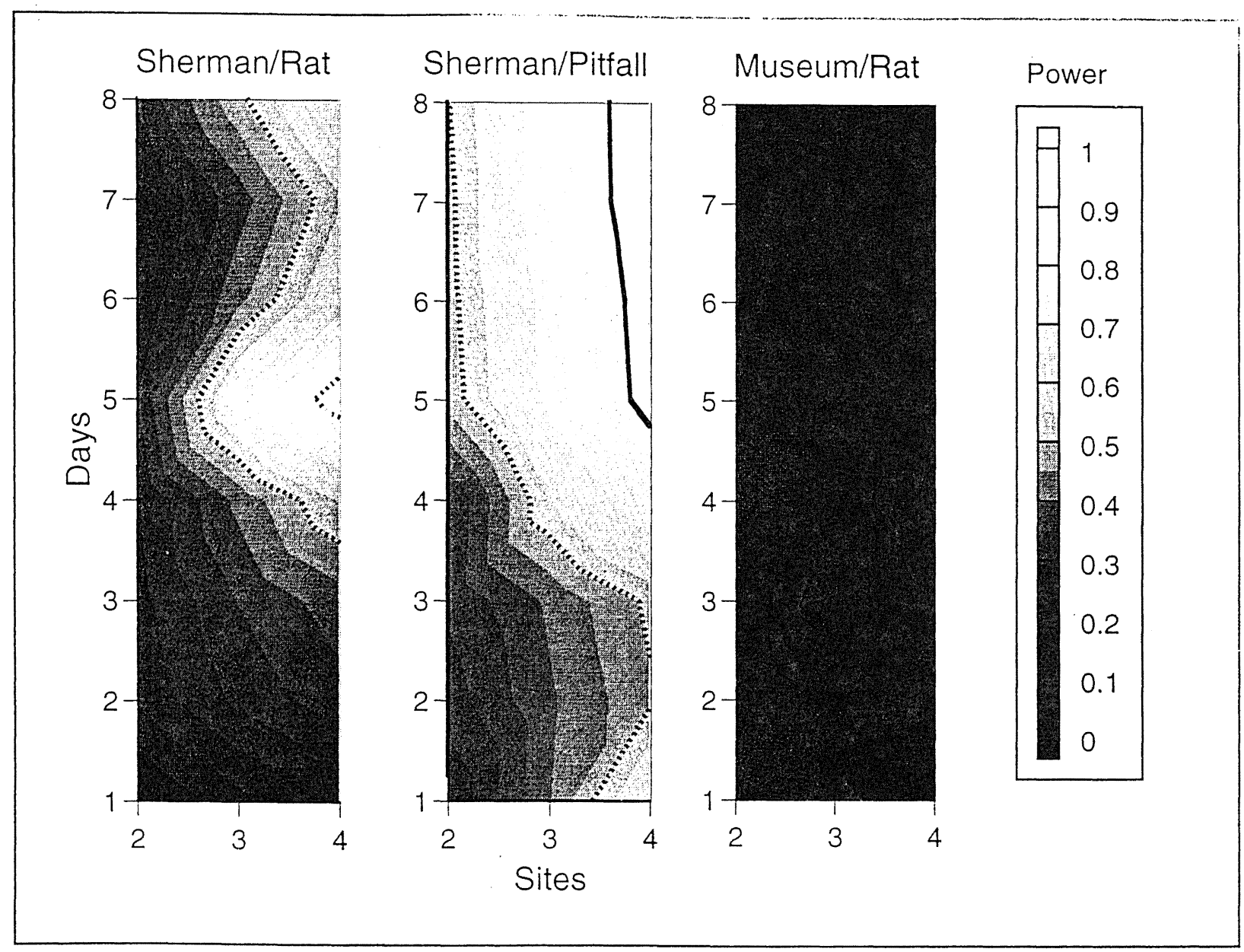

Figure 12. Power to detect differences in small mammal community composition at Fort Hood.

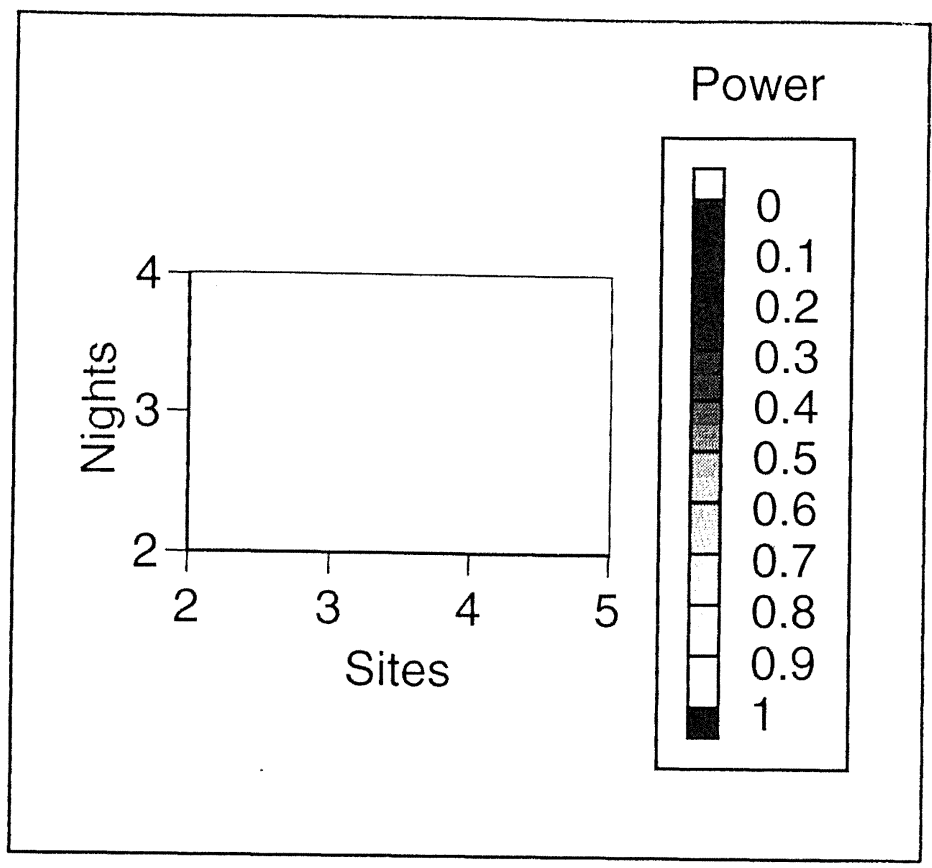

Figure 13. Power to detect differences in small mammal community composition at Fort Bliss. 
Table 10. Diversity index values from pooled avian and small mammal data.

\begin{tabular}{|c|c|c|c|c|c|c|c|}
\hline \multirow{2}{*}{\begin{tabular}{|l|} 
Index \\
\end{tabular}} & \multirow[b]{2}{*}{ Symbol } & \multicolumn{2}{|c|}{ Camp Florence } & \multicolumn{2}{|c|}{ Fort Hood } & \multicolumn{2}{|c|}{ Fort Bliss } \\
\hline & & Cactus & Creosote & Savannah & Forest & Arroyo & Upland \\
\hline \multicolumn{8}{|l|}{ Birds } \\
\hline Number of Species & $S$ & 23 & 26 & 25 & 25 & 45 & 21 \\
\hline $\begin{array}{l}\text { Reciprocal of Simpson's } \\
\text { index }\end{array}$ & $\mathrm{d}_{\mathrm{s}}$ & 6.2 & 9.5 & 9.5 & 9.1 & 11.3 & 5.3 \\
\hline Shannon's Index & $\mathrm{H}^{\prime}$ & 2.3 & 2.3 & 2.6 & 2.5 & 2.8 & 2.2 \\
\hline Fisher's $\alpha$ & $\alpha$ & 3.9 & 4.8 & 4.3 & 4.3 & 9.7 & 4.8 \\
\hline \multicolumn{8}{|l|}{ Mammals } \\
\hline Number of Species & $S$ & 9 & 11 & 9 & 6 & 14 & 14 \\
\hline $\begin{array}{l}\text { Reciprocal of Simpson's } \\
\text { index }\end{array}$ & $\mathrm{d}_{\mathrm{s}}$ & 2.4 & 4.7 & 5.6 & 1.9 & 5.5 & 7.7 \\
\hline Shannon's Index & $\mathrm{H}^{\prime}$ & 1.3 & 1.8 & 1.9 & 1.0 & 2.0 & 2.2 \\
\hline Fisher's $\alpha$ & $\alpha$ & 1.7 & 2.4 & 3.2 & 1.7 & 2.9 & 2.6 \\
\hline
\end{tabular}

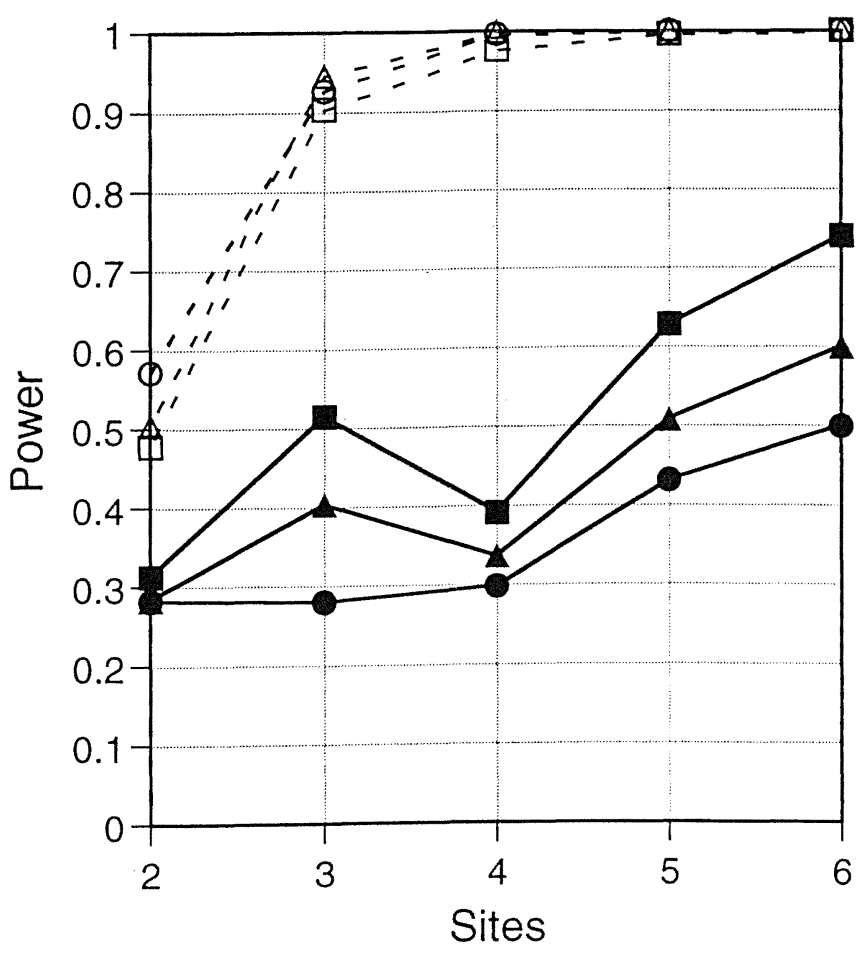

\begin{tabular}{|l|lr|}
\hline & 1993 & 1994 \\
\hline$S$ & $-\square$ & $-\square$ \\
$d_{S}$ & - & $-\Theta$ \\
$H^{\prime}$ & -4 & $-\Delta$ \\
\hline
\end{tabular}

Figure 14. Power to detect differences in avian community diversity at Fort Bliss. 
Table 11. Statistical power associated with diversity index values of small mammal captures.

\begin{tabular}{|l|c|c|c|c|c|c|c|c|c|c|c|}
\hline & & \multicolumn{3}{|c|}{$\begin{array}{c}\text { Camp Florence } \\
\text { Sites }\end{array}$} & \multicolumn{3}{c|}{ Fort Hood } & \multicolumn{4}{c|}{ Fort Bliss } \\
Sites
\end{tabular}

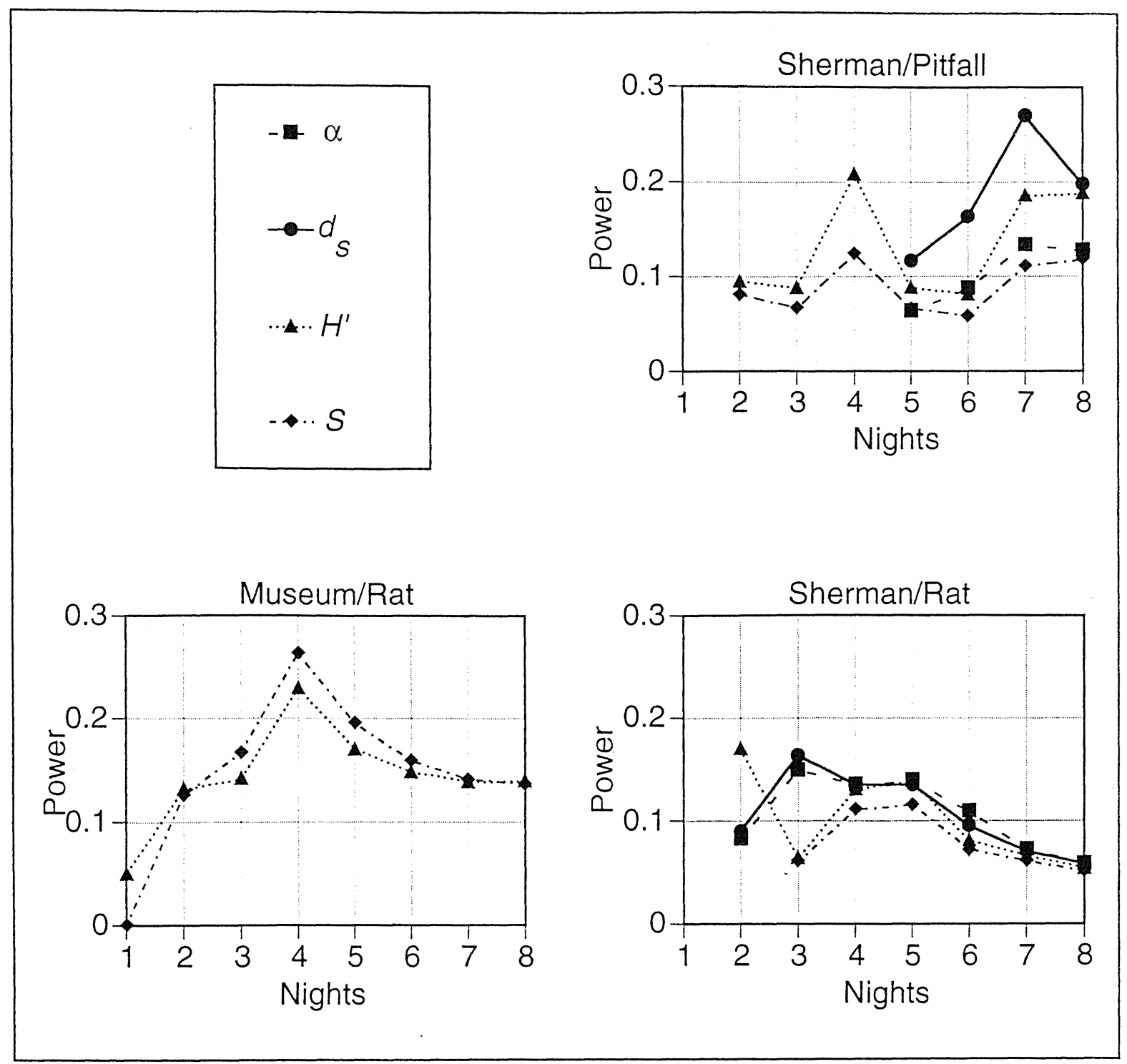

Figure 15. Power to detect differences in small mammal community diversity at Camp Florence (not pooled over days). 


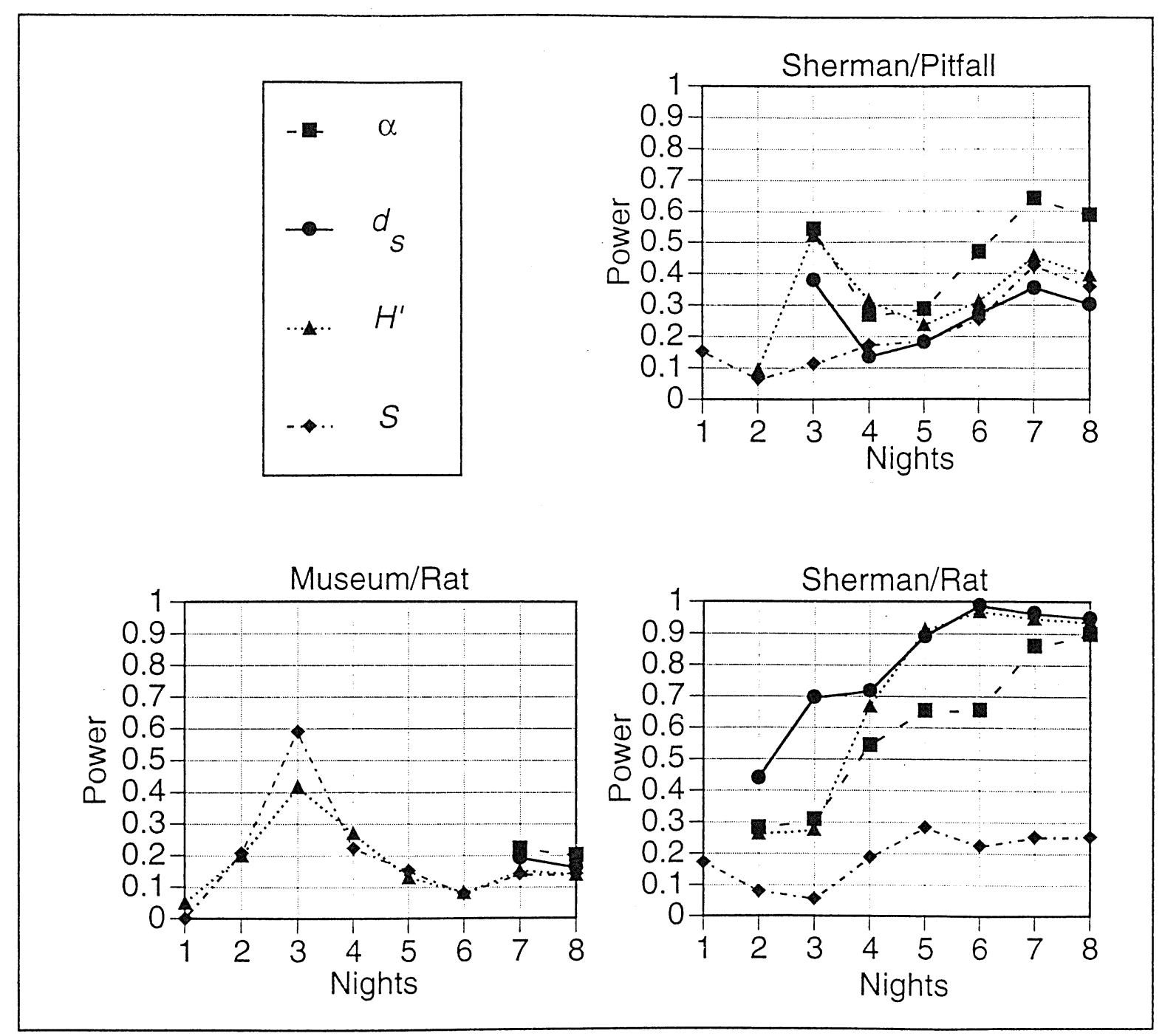

Figure 16. Power to detect differences in small mammal community diversity at Camp Florence (pooled over days). 


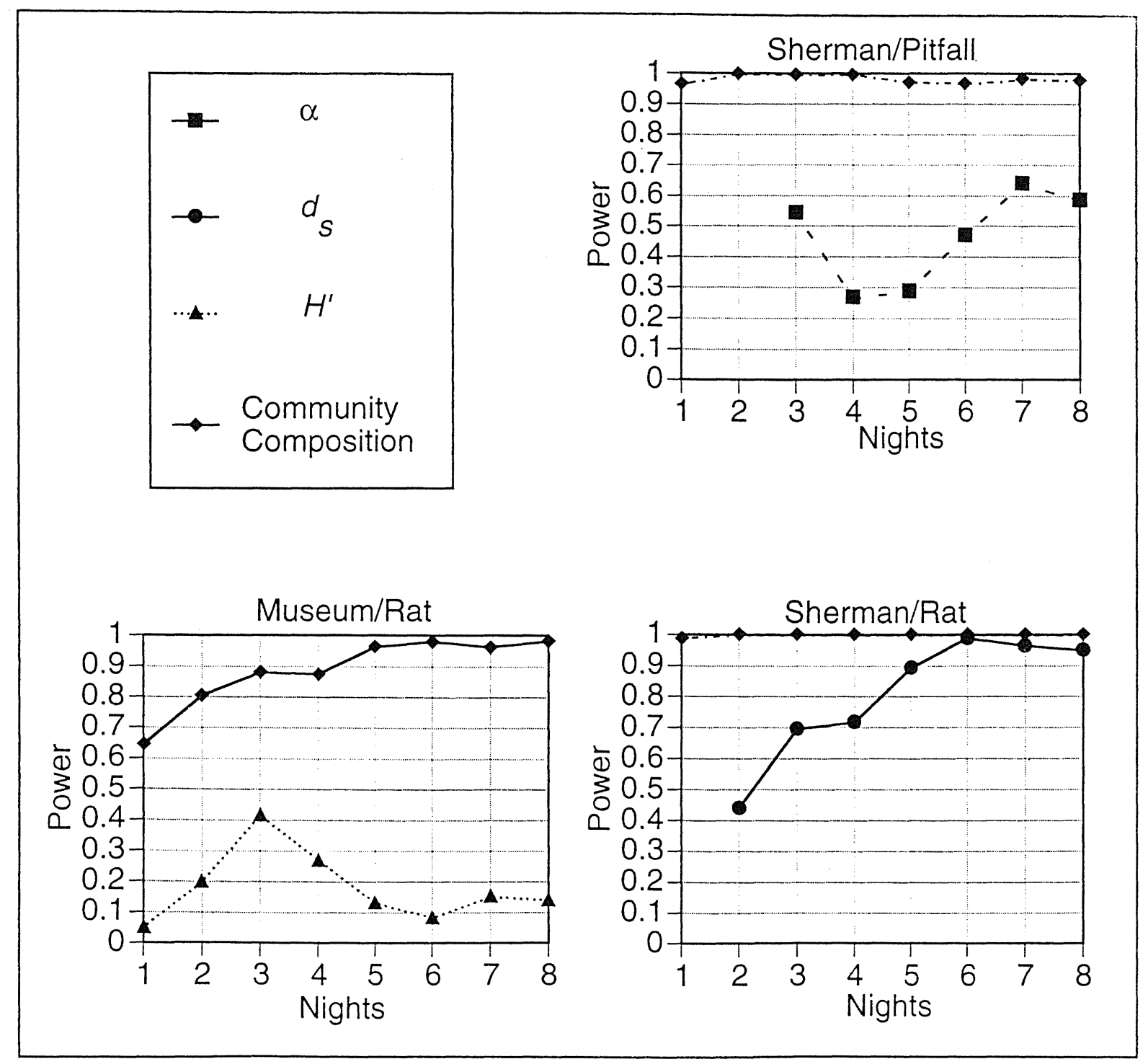

Figure 17. Comparison of power to detect differences in small mammal community diversity found in two habitats at Camp Florence using community composition and the best diversity index. 


\section{Discussion}

Statistical power for main effects was consistently lower than that for the interaction. That is, species responses to habitat differences were more rapidly detected as changes in the relative abundance among species (changes in community composition) than changes in abundance for all species.

\section{Avian Communities}

At Camp Florence, the transect portions of the survey yielded more power than the point count. Point counts, in one form or another, are widely used in conducting bird surveys (Lancia, Nichols, and Pollock 1994) in forests or areas with rough terrain. Point counts allow the observer to concentrate on counting birds rather than simultaneously counting and negotiating difficult terrain features. Habitats on Camp Florence are fairly open desert scrub associations, which may allow easier detection of birds that are disturbed as a surveyor proceeds along the transect.

The behavior of desert birds may also contribute to higher power resulting from counts during the walking portion of the LCTA survey than during the point count survey. Temperatures often increase rapidly following sunrise and remain high throughout the day, thereby forcing birds to seek shade. Desert birds typically seek shade and remain relatively sedentary during the heat of the day to conserve water (Welty and Baptista 1988). Observers conducting transects would likely disturb birds that may not have been detected during point counts. Consequently, the effect of desert heat in influencing bird behavior should be considered when conducting surveys on installations in arid regions.

Given the higher power on transects at Camp Florence, it is not clear why power for the walking out portion of the bird surveys was higher than for the walking in portion. These two surveys covered the same ground in opposite directions. This means that for the walk out, the transect had been recently disturbed (during the walk in), but why this might yield higher power is uncertain. 


\section{Small Mammal Communities}

In this study, arrays incorporating Sherman live traps yielded more power than arrays containing Museum Special snap traps, which are currently specified for LCTA small mammal trapping. The use of pitfall traps did not appreciably improve power so the use of this labor intensive method was not supported.

\section{Diversity Indices}

Diversity indices are a convenient means of summarizing community structure with a single number. Statistical power associated with analysis of diversity indices was substantially lower than comparisons involving community composition. This may be related to the reductionist characteristic of diversity indices, which reflect only certain types of community differences. Frequently, it was not possible to calculate (and consequently analyze) some of the diversity indices due to computational limitations. For example, it was not possible to calculate $d_{s}$ when $\sum n_{\mathrm{i}}\left(\mathrm{n}_{\mathrm{i}}-1\right)=0$ or Fisher's $\alpha$ when $N=\mathrm{S}$. This occurred when low numbers of individuals of only a few species were found. As a result of incalculable index values, it often was not feasible to compare indices using ANOVA.

\section{Effect Size}

This analysis used the effect size exhibited by the data sets from each test to evaluate power. As a result, lack of power did not necessarily mean the methods were inadequate, but simply that the effect size was small. Without specifying a particular effect size, the appropriate use of this analysis is to compare one field technique or analytical approach with others using the same data set. For example, the fact that power was high for all types of mammal trapping arrays at Camp Florence, but smaller for all trap array types at Fort Hood, does not mean that mammal trapping worked better at Camp Florence. It may mean only that community differences were of a different magnitude at the two installations. The appropriate comparison is within each installation; which technique or approach yielded the higher power. It is then of interest to see if such comparisons show a consistent pattern or not.

Direct comparisons between installations would require that a standard effect size be applied to the analysis. Determining which effect size to use is a relatively easy judgment to make for main effects, but this analysis focused in the interaction effect (species by habitat). Judging what level of community change it is desirable to detect 
is much more difficult. There are two possible approaches for making this judgment. The first is to use the similarity indices to assess the magnitude of the differences between the communities to evaluate power. The second is to assess the interaction effects of a number of other studies (such as environmental impact studies), and classify them subjectively according to degree of community difference and then use this classification as a standard for evaluating power. Both of these approaches are possible extensions of this research effort.

\section{Sample Design}

There was no consistent indication that power increased more with either increasing sampling sites or sampling days, but it appeared that increasing the number of sites was more important at Camp Florence, whereas the opposite was true at Fort Bliss (Table 12).

Table 12. Relative increase in power by increasing sampling by number of sites or number of days (or nights).

\begin{tabular}{|l|c|c|c|c|}
\hline & \multicolumn{4}{|c|}{ Mammals } \\
\hline & Birds & Sherman/Rat & Sherman/Pitfall & Museum/Rat \\
\hline Camp Florence & Equal & Equal & Sites & Sites \\
\hline Fort Hood & NA & NA & Equal & NA \\
\hline Fort Bliss & Days & Nights & - & - \\
\hline $\begin{array}{l}\text { "-" indicates no sample. } \\
\text { "NA" indicates an assessment could not be made because of high variation in the power estimates. }\end{array}$
\end{tabular}




\section{Conclusions and Recommendations}

Statistical power is an appropriate measure of the effectiveness of monitoring methods, since it is based on statistical procedures used in the evaluation.

For surveying birds in desert habitats, walking transects appear to be more effective than point counts. This is probably related to the habitat structure and behavior of the birds.

For small mammals, the power of community comparisons was lower using Museum Special snap traps, compared with arrays using Sherman live traps. The reason for this was not evident.

Although diversity indices provide important information on community structure, they were relatively unsuitable for reliably detecting differences between communities. Low power values and the high frequency of incalculable index values made community comparisons between habitats statistically of little use. A lack of detectable differences between communities may have been because the communities are similar, or because the communities have similar structure but differing composition.

Nationwide standard methods of monitoring Army lands are likely to result in variable efficiency and effectiveness among locations. Therefore, the minimum necessary degree of standardization should be identified and incorporated into the sampling regime, while still allowing for the maximum amount of adaptation of protocols for specific ecosystems. It may be preferable to specify inventory and monitoring standards that need to be achieved, as opposed to specifying particular methods and designs. 


\section{References}

Bray, J.R. and C.T. Curtis, "An Ordination of the Upland Forest Communities of Southern Wisconsin," Ecological Monographs, vol 27 (1957), pp 325-349.

Bury, R.B. and P.S. Corn, "Evaluation of Pitfall Trapping in Northwestern Forests: Trap Arrays with Drift Fences," Journal of Wildlife Management, vol 51 (1987), pp 113-119.

Cohen, J., Statistical Power Analysis for the Behavioral Sciences (Lawrence Erlbaum Assocs., Inc., Hillsdale, NJ, 1988).

Dunn, O.J. and V.A. Clark, Applied Statistics: Analysis of Variance and Regression (John Wiley and Sons, Inc, New York, NY, 1974).

Diersing, V.E., R.B. Shaw and D.J. Tazik, "U.S. Army Land Condition-Trend Analysis (LCTA) Program," Environmental Management, vol 16 (1992), pp 404-414.

Fisher, R.A., A.S. Corbet, and C.B. Williams, "The Relation Between the Number of Species and the Number of Individuals in a Random Sample of an Animal Population," Journal of Animal Ecology, vol 12 (1943), pp 42-58.

Horn, H., "Measurement of Overlap in Comparative Ecological Studies," American Naturalist, vol 100 (1966), pp 419-424.

Jaccard, P., "Nouvelles Recherches sur la Distribution Florale," Bulletin. Societe Vaudoise des Sciences Naturelles, vol 44 (1908), pp 223-270.

Lancia, R.A., J.D. Nichols, and K.H. Pollock, "Estimating the Number of Animals in Wildlife Populations," Research and Management Techniques for Wildlife and Habitats, T.A. Bookhout, ed., (Allen Press, Inc., Lawrence, KS, 1994), pp 215-253.

Lipsey, M.W., Design Sensitivity: Statistical Power for Experimental Research (Sage Publications, Inc., Newbury Park, London, England 1990).

McIntosh, R.P., "An Index of Diversity and the Relation of Certain Concepts to Diversity," Ecology, vol 48 (1967), pp 392-404.

Norusis, M.J., SPSS Advanced Statistics, (SPSS Inc., Chicago, IL, 1993).

Pielou, E.C., Ecological Diversity (John Wiley and Sons, New York, NY, 1975). 
Price, D.L., A.B. Anderson, W.R. Whitworth, and P.J. Guertin, Land Condition Trend Analysis Data Summaries: Preliminary Data Applications, Technical Report 95/39/ADA300753 (U.S Army Construction Engineering Research Laboratories [USACERL], September, 1995).

Renzulli, C.B., J.F. Flowers, and R.H. Tamarin, "The Effects of Trapping Design on Demographic Estimates in the Meadow Vole, Microtus pennsylvanicus," American Midland Naturalist, vol 104 (1980), pp 397-401.

Rice, C.G., S. Demarais, and R.W. Hansen, "Statistical Power for Evaluating Monitoring Methods and Analysis for the Army's Land Condition Trend Analysis Program," in Measuring and Monitoring Forest Biological Diversity, F. Dallmier ed., (Smithsonian Inst./MAB International Symposium), in press.

Shannon, C.E. and W. Weaver, The Mathematical Theory of Communication (Univ. of Illinois Press, Urbana, IL, 1949).

Simpson, E.H., "Measurement of Diversity," Nature, vol 163 (1949), p 688.

Tazik, D.J, S.D. Warren, V.E. Diersing, R.B. Shaw, R.J. Brozka, C.F. Bagley, and W.R. Whitworth, U.S. Army Land Condition-Trend Analysis (LCTA) Plot Inventory Field Methods, Technical Report N-92/03/ADA247931 (U.S. Army Construction Engineering Research Laboratories [USACERL], February, 1992).

Welty, J.C. and L. Baptista, The Life of Birds, (Saunders College Publ., New York, NY, 1988).

Wolda, H., "Similarity Indices, Sample Size and Diversity," Oecologia, vol 50 (1981), pp 296-302. 


\section{USACERL DISTRIBUTION}

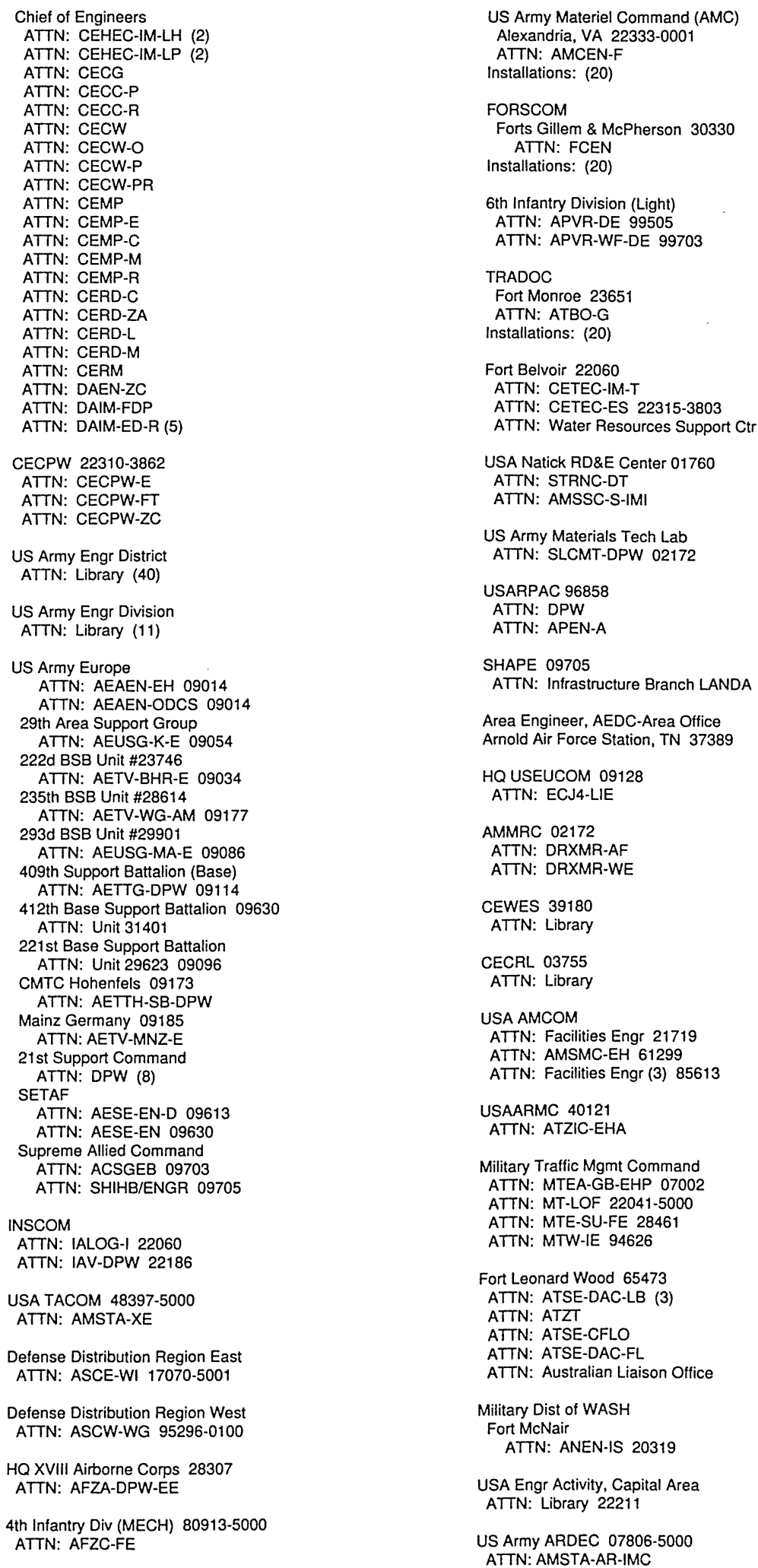

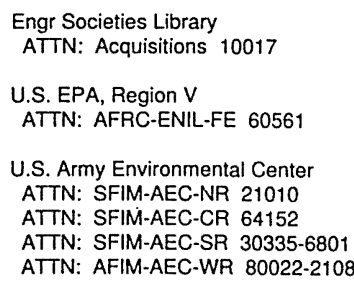

Tyndall AFB 32403 ATTN: HQAFCESAICES ATTN: Engrg \& Srvc Lab

USA TSARCOM 63120

ATTN: STSAS-F

American Public Works Assoc. 64104-1806

US Army CHPPM

ATTN: MCHB-DE 21010

US Gov't Printing Office 2040 ATTN: Rec Sec/Deposit Sec (2)

Nat'I Institute of Standards \& Tech ATTN: Library 20899

Defense General Supply Center ATTN: DGSC-WI 23297-5000

Defense Construction Supply Center ATTN: DCSC-WI 43216-5000

Defense Tech Info Center 22060-6218 ATTN: DTIC-O (2) 
DEPARTMENT OF THE ARMY

CONSTRUCTION ENGINEERING RESEARCH LABORATORIES

CORPS OF ENGINEERS

$$
\text { PO BOX } 9005
$$

CHAMPAIGN, ILLINOIS $61826-9005$

OFFICIAL BUSINESS 